\title{
Seasonality of isoprenoid emissions from a primary rainforest in central Amazonia
}

Eliane G. Alves ${ }^{1}$, Kolby Jardine ${ }^{2}$, Julio Tota ${ }^{3}$, Angela Jardine ${ }^{1}$, Ana Maria Yãnez-Serrano ${ }^{1,4}$, Thomas Karl ${ }^{5}$, Julia Tavares $^{6}$, Bruce Nelson ${ }^{6}$, Dasa Gu ${ }^{7}$, Trissevgeni Stavrakou ${ }^{8}, \operatorname{Scot}_{\text {Martin }^{9}}$, Paulo Artaxo ${ }^{10}$, Antonio Manzi ${ }^{1,11}$, and Alex Guenther ${ }^{7}$

${ }^{1}$ Climate and Environment Department, National Institute for Amazonian Research (INPA) and State University of Amazonas (UEA), Av. André Araújo 2936, CEP 69067-375, Manaus-AM, Brazil

${ }^{2}$ Climate Science Department, Earth Science Division, Lawrence Berkeley National Laboratory (LBNL), One Cyclotron Rd, building 64-241, Berkeley, CA 94720, USA

${ }^{3}$ Institute of Engineering and Geoscience, Federal University of West Para (UFOPA), Rua Vera Paz s/n, CEP 68035-110,

Santarem-PA, Brazil

${ }^{4}$ Biogeochemistry Department, Max Planck Institute for Chemistry, P.O. Box 3060, 55128, Mainz, Germany

${ }^{5}$ Institute for Meteorology and Geophysics, University of Innsbruck, Innrain 52, 6020, Innsbruck, Austria

${ }^{6}$ Ecology Department, National Institute for Amazonian Research (INPA), Av. André Araújo 2936, CEP 69067-375,

Manaus-AM, Brazil

${ }^{7}$ Department of Earth System Science, University of California, Irvine, USA

${ }^{8}$ Belgian Institute for Space Aeronomy, Avenue Circulaire 3, 1180 Uccle, Brussels, Belgium

${ }^{9}$ School of Engineering and Applied Sciences, Department of Earth and Planetary Sciences, Harvard University,

29 Oxford St, Cambridge, MA 02138, USA

${ }^{10}$ Institute of Physics, University of Sao Paulo, Rua Matão, Travessa R, 187 - Cidade Universitária, CEP 05508-900,

Sao Paulo-SP, Brazil

${ }^{11}$ National Institute for Spatial Research, Center of Weather Forecasting and Climate Studies, Rod. Presidente Dutra, km 40, Cachoeira Paulista/SP, Brazil

Correspondence to: Eliane G. Alves (elianegomes.alves@gmail.com)

Received: 23 September 2015 - Published in Atmos. Chem. Phys. Discuss.: 26 October 2015

Revised: 26 February 2016 - Accepted: 2 March 2016 - Published: 23 March 2016

\begin{abstract}
Tropical rainforests are an important source of isoprenoid and other volatile organic compound (VOC) emissions to the atmosphere. The seasonal variation of these compounds is however still poorly understood. In this study, vertical profiles of mixing ratios of isoprene, total monoterpenes and total sesquiterpenes, were measured within and above the canopy, in a primary rainforest in central Amazonia, using a proton transfer reaction - mass spectrometer (PTR-MS). Fluxes of these compounds from the canopy into the atmosphere were estimated from PTR-MS measurements by using an inverse Lagrangian transport model. Measurements were carried out continuously from September 2010 to January 2011, encompassing the dry and wet seasons. Mixing ratios were higher during the dry (isoprene -
\end{abstract}

$2.68 \pm 0.9 \mathrm{ppbv}$, total monoterpenes $-0.67 \pm 0.3 \mathrm{ppbv}$; total sesquiterpenes $-0.09 \pm 0.07 \mathrm{ppbv}$ ) than the wet season (isoprene $-1.66 \pm 0.9 \mathrm{ppbv}$, total monoterpenes $-0.47 \pm$ $0.2 \mathrm{ppbv}$; total sesquiterpenes $-0.03 \pm 0.02 \mathrm{ppbv}$ ) for all compounds. Ambient air temperature and photosynthetically active radiation (PAR) behaved similarly. Daytime isoprene and total monoterpene mixing ratios were highest within the canopy, rather than near the ground or above the canopy. By comparison, daytime total sesquiterpene mixing ratios were highest near the ground. Daytime fluxes varied significantly between seasons for all compounds. The maximums for isoprene $\left(2.53 \pm 0.5 \mu \mathrm{mol} \mathrm{m}^{-2} \mathrm{~h}^{-1}\right)$ and total monoterpenes $\left(1.77 \pm 0.05 \mu \mathrm{mol} \mathrm{m}^{-2} \mathrm{~h}^{-1}\right)$ were observed in the late dry season, whereas the maximum for total sesquiterpenes 
was found during the dry-to-wet transition season $(0.77 \pm$ $0.1 \mu \mathrm{mol} \mathrm{m}^{-2} \mathrm{~h}^{-1}$ ). These flux estimates suggest that the canopy is the main source of isoprenoids emitted into the atmosphere for all seasons. However, uncertainties in turbulence parameterization near the ground could affect estimates of fluxes that come from the ground. Leaf phenology seemed to be an important driver of seasonal variation of isoprenoid emissions. Although remote sensing observations of changes in leaf area index were used to estimate leaf phenology, MEGAN 2.1 did not fully capture the behavior of seasonal emissions observed in this study. This could be a result of very local effects on the observed emissions, but also suggest that other parameters need to be better determined in biogenic volatile organic compound (BVOC) models. Our results support established findings that seasonality of isoprenoids are driven by seasonal changes in light, temperature and leaf phenology. However, they suggest that leaf phenology and its role on isoprenoid production and emission from tropical plant species needs to be better understood in order to develop mechanistic explanations for seasonal variation in emissions. This also may reduce the uncertainties of model estimates associated with the responses to environmental factors. Therefore, this study strongly encourages long-term measurements of isoprenoid emissions, environmental factors and leaf phenology from leaf to ecosystem scale, with the purpose of improving BVOC model approaches that can characterize seasonality of isoprenoid emissions from tropical rainforests.

\section{Introduction}

Terrestrial vegetation emits high quantities of biogenic volatile organic compounds (BVOCs) to the atmosphere (Guenther et al., 2006, 2012), which are removed by oxidation reactions, deposition of reaction products (Lelieveld et al., 2008) and consumption by surfaces (Gray et al., 2014). Emissions and subsequent transformations in the atmosphere have been widely explored by the scientific community. However, there is still a need for improving our understanding of how BVOC emissions and their reaction products vary seasonally and are involved in atmosphere chemistry, biogeochemical cycling and climate at local, regional, and global scales.

Despite a large number of BVOC species that have been identified within plants and in emissions from plants, the largest part of the global biogenic emissions and subsequent effect on atmospheric chemistry are thought to be associated with isoprenoids (Laothawornkitkul et al., 2009). The isoprenoids are an important class of organic compounds that include isoprene (containing five carbon atoms $-\mathrm{C}_{5}$ ), monoterpenes (10 carbon atoms $\left.-\mathrm{C}_{10}\right)$, sesquiterpenes $(15$ carbon atoms $-\mathrm{C}_{15}$ ), and diterpenes ( 20 carbon atoms $-\mathrm{C}_{20}$ ) (Guenther, 2002).
Isoprene, as the building block of the higher-order isoprenoids, is the dominant compound in emissions from many landscapes and has the single largest contribution to total global vegetation BVOC emission, with an estimated global annual emission of about $400-600 \mathrm{Tg}$ C (see Table 1 of Arneth et al., 2008). Even though there are more than 1000 monoterpene compounds identified in plants, only a few (less than 12) monoterpenes comprise a large fraction of total monoterpene emissions into the atmosphere. (Guenther, 2002). Compounds such as $\alpha$-pinene, $\mathrm{t}-\beta$-ocimene, $\beta$-pinene, limonene, sabinene, myrcene, 3-carene, camphene, $\beta$-phellandrene and terpinolene dominate monoterpene emissions globally (Guenther et al., 2012). However, at regional scales other monoterpene compounds may also be important (Geron et al., 2000; Jardine et al., 2015). Only a few (e.g., $\beta$-caryophyllene) of about 3000 sesquiterpenes and none of the 2000 diterpenes are known to be emitted into the atmosphere in considerable amounts (Guenther, 2002). However, there are many compounds in the atmosphere that are still unknown or unexplored (Goldstein et al., 2007; Park et al., 2013), suggesting that the characterization of sesquiterpene emissions and other trace gases is still an open question.

Although models indicate that tropical rainforests are the main source of isoprenoid emissions to the global atmosphere (Guenther et al., 2012), estimates of global annual emissions of isoprenoid still have large uncertainties (Guenther et al., 2006). One approach to constraining these estimates, specifically for isoprene, is the use of remotely sensed concentrations of BVOC oxidation products in the atmosphere in order to make top-down model estimates (Barkley et al., 2008, 2009, 2013; Stavrakou et al., 2009, 2015). This approach has also suggested seasonal patterns in the emissions of this organic compound (Barkley et al., 2009). In addition, seasonal variations of isoprene emissions in the Amazonian rainforest are suggested based on comparison of some studies with intensive campaigns in situ (Table 1). This seasonality may be driven by light and temperature seasonal variation and leaf phenology (Barkley et al., 2009), and seasonal changes in insolation is probably the main driver of leaf phenology (Jones et al., 2014).

Therefore, the objective of this study was to quantify the seasonal variation of mixing ratios and emissions of isoprene, total monoterpenes and total sesquiterpenes in a primary rainforest in central Amazonia and to correlate them to seasonal variations of environmental (temperature and light) and biological (leaf phenology) factors.

\section{Material and methods}

\subsection{Site description}

Isoprenoid vertical profiles were investigated at the triangular tower (TT34 tower $-2^{\circ} 35.37^{\prime} \mathrm{S}, 60^{\circ} 06.92^{\prime} \mathrm{W}$ ) on a plateau of the Cuieiras Biological Reserve, a primary rainforest re- 


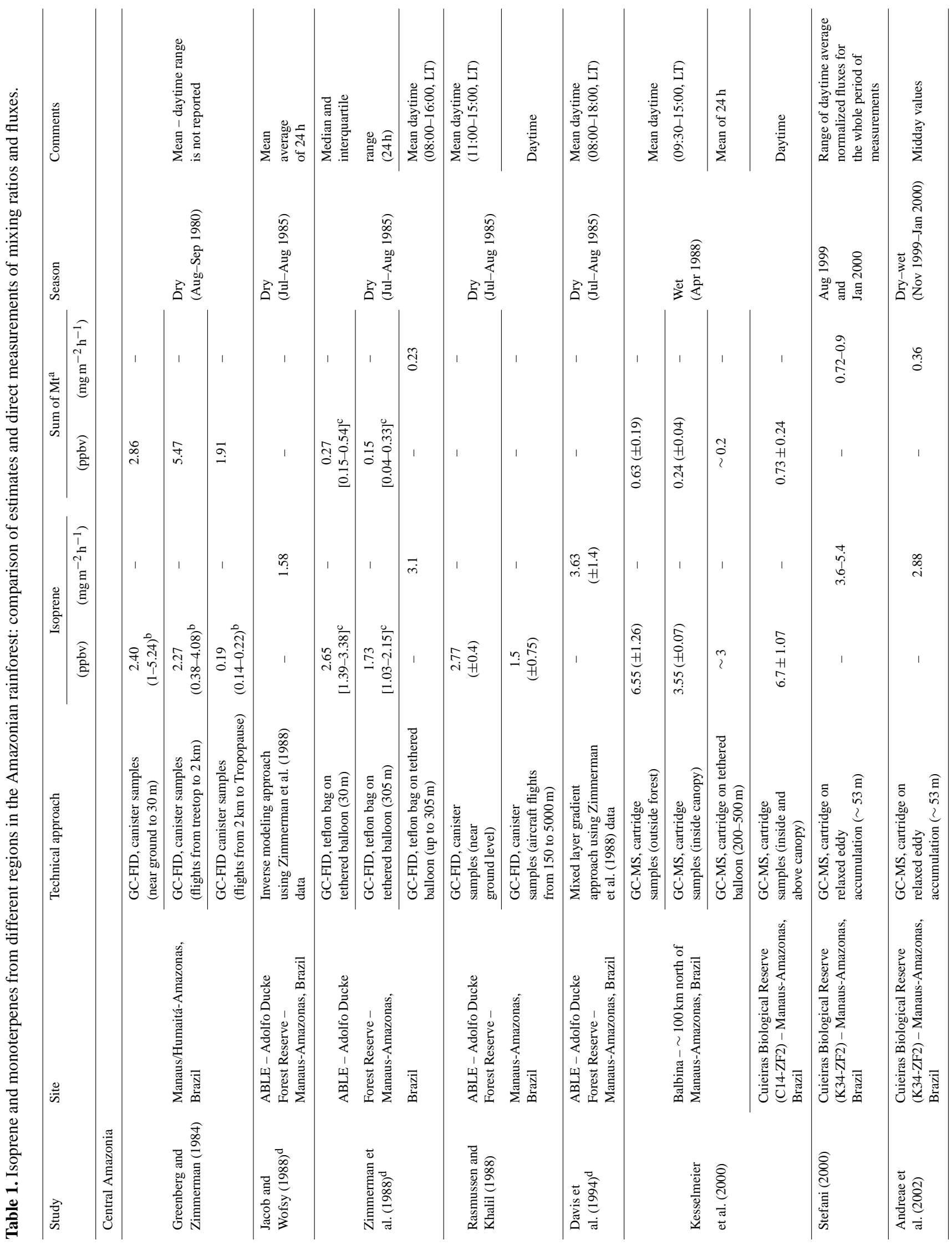




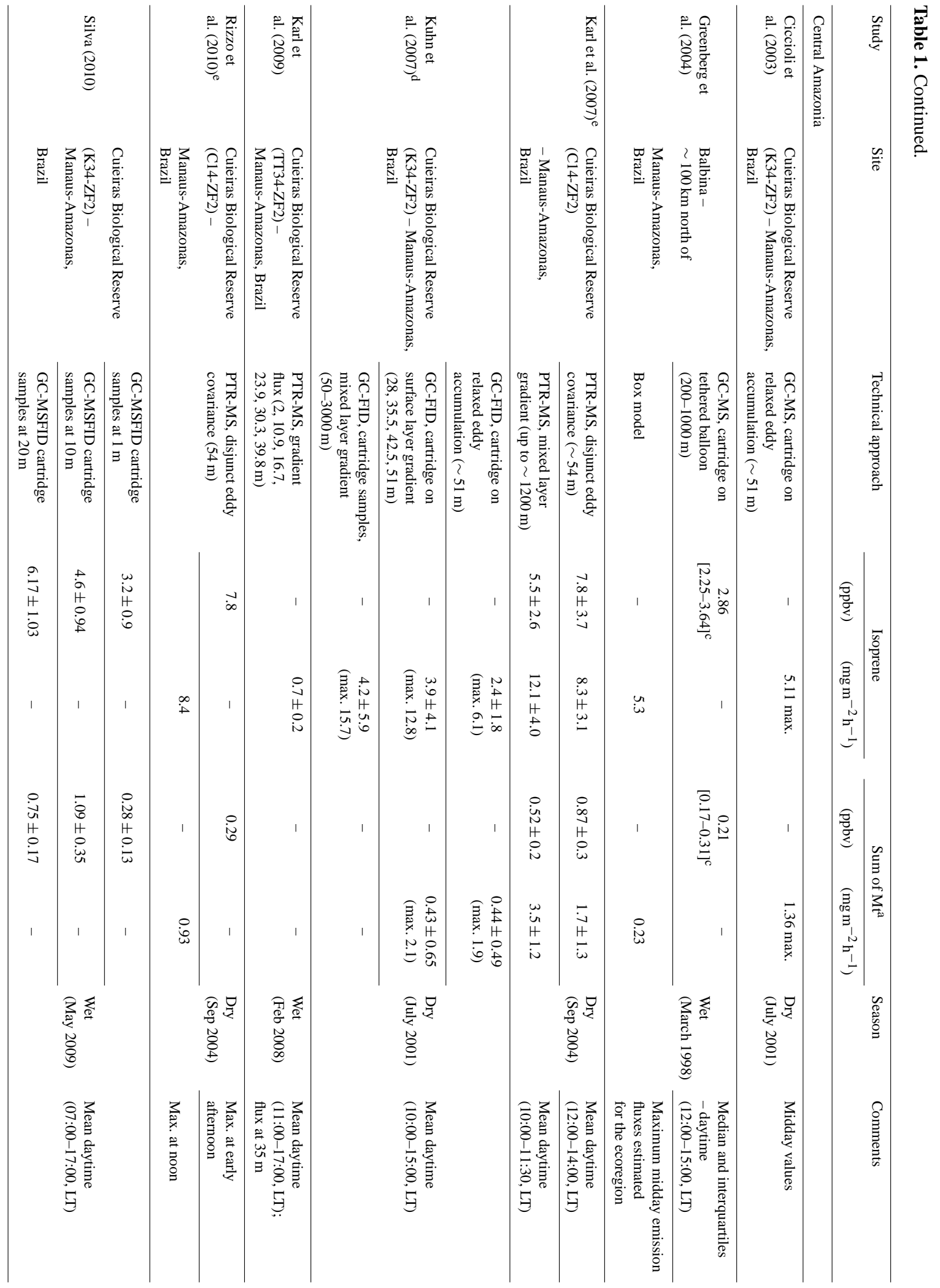




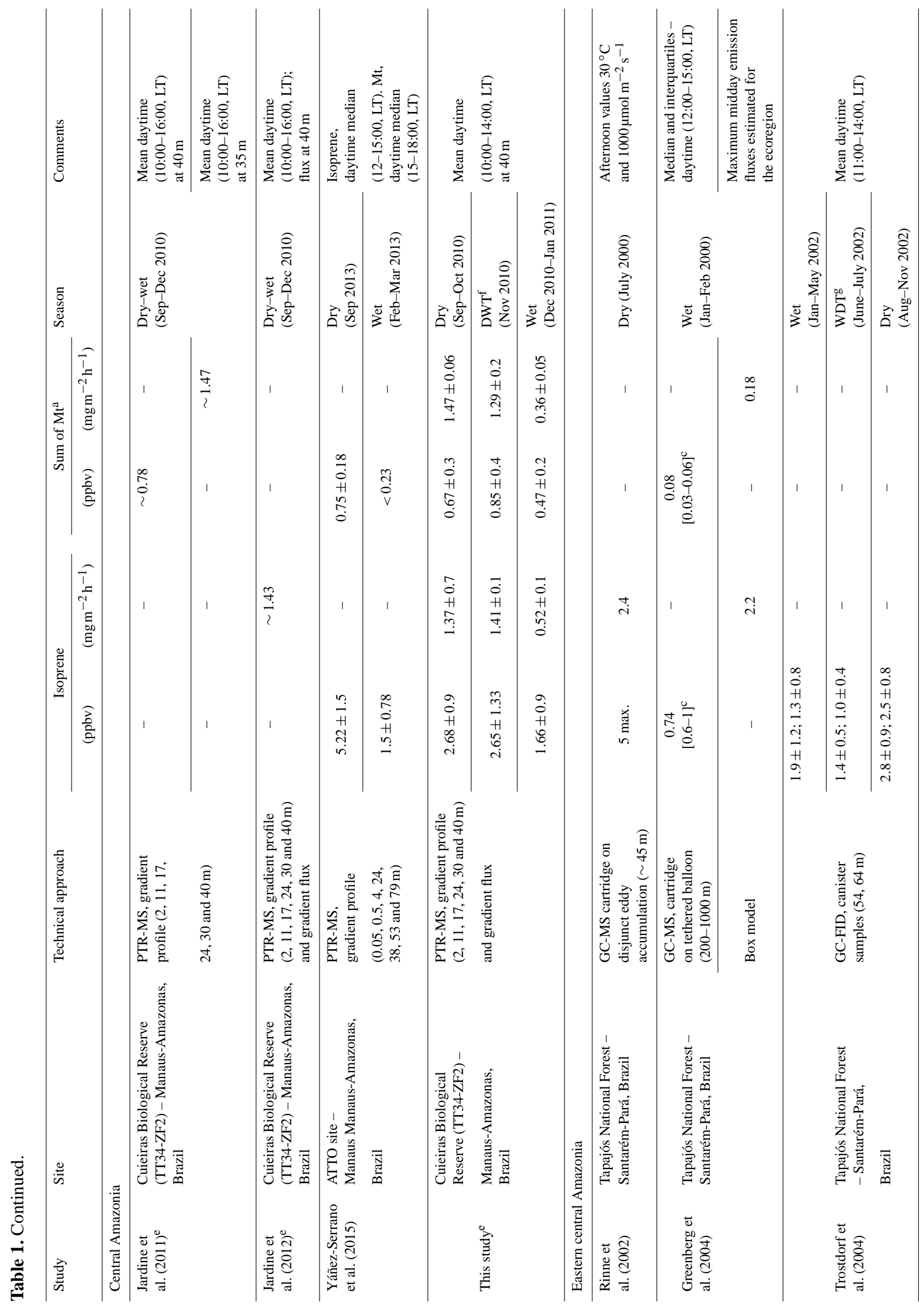




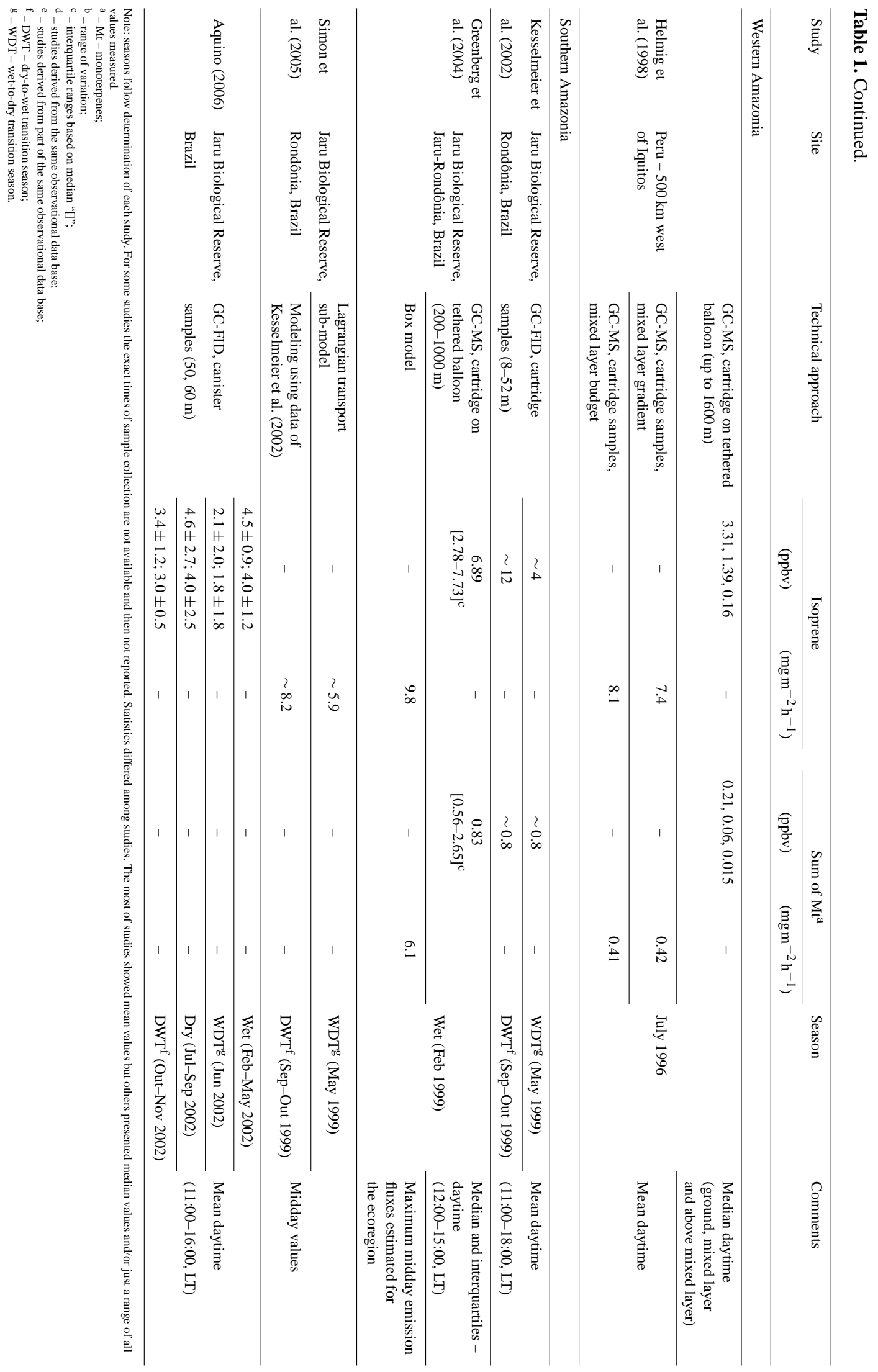



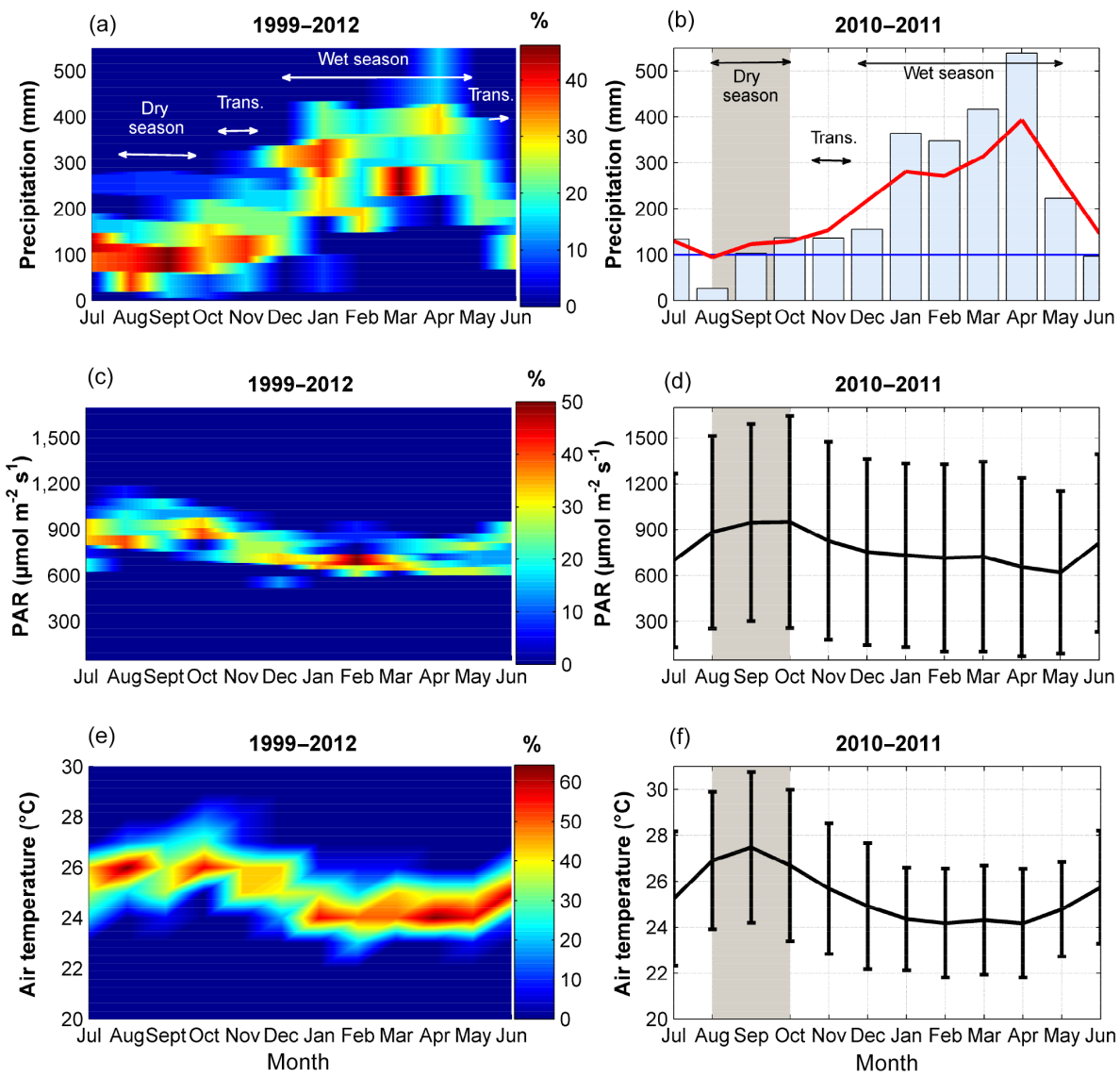

Figure 1. Precipitation, PAR and air temperature measured at K34 tower ( $\sim 2 \mathrm{~km}$ far of TT34 tower): (a) relative frequency (\%) of monthly cumulative precipitation from 1999 to 2012; (b) monthly cumulative precipitation from July 2010 to June 2011 (measured in 30 min intervals for $24 \mathrm{~h}$ ) (bars), and average of monthly cumulative precipitation from 1999 to 2012 (red line); (c) relative frequency of monthly PAR from 1999 to 2012 (measured every 30 min during 06:00-18:00, LT); (d) monthly average PAR from July 2010 to June 2011 (measured every 30 min during 06:00-18:00, LT); (e) relative frequency of monthly air temperature from 1999 to 2012; (f) monthly average air temperature from July 2010 to June 2011 (measured in 30 min intervals for $24 \mathrm{~h}$ ). Figures on the right side cover the period of this study; grey areas represent the period of dry season; and blue line at (b) represents $100 \mathrm{~mm} \mathrm{month}^{-1}$. Error bars represent 1 standard deviation.

serve located approximately $60 \mathrm{~km}$ northwest of Manaus city, in the central Amazonian Basin, in Amazonas, Brazil (Martin et al., 2010). The vegetation in this area is considered to be a mature terra firme rain forest (Pires and Prances, 1985), with a leaf area index of 4.7 (Malhi et al., 2009). The diversity of tree species is above 200 species ha $^{-1}$ (Oliveira et al., 2008). Annual precipitation is about $2500 \mathrm{~mm}$ (Fig. 1a), with December-May being the wetter period. Although severe droughts impacted part of the Amazon basin in 2005 and in 2010, those droughts did not affect central Amazonia (Marengo et al., 2008, 2011). However, micrometeorological measurements from 1999 to 2012 showed that from August to September the monthly cumulative precipitation can be less than $100 \mathrm{~mm}$ per month (Fig. 1a), characterizing this period as dry season. Average air temperature ranges between $24^{\circ} \mathrm{C}$ (in April) and $27^{\circ} \mathrm{C}$ (in September) (Fig. 1e). Soil moisture near the surface is slightly reduced (by $10 \%$ ) during the dry compared to the wet season (Cuartas et al., 2012).
The period of this study (from 2 September 2010 to 27 January 2011) represents the second half of the dry season (September 2010-October 2010), the dry-to-wet transition season (November 2010), and the beginning of the wet season (December 2010-January 2011). The whole period of measurements includes the period of low precipitation and when precipitation is increasing (Fig. 1b), and when photosynthetically active radiation (PAR) (Fig. 1d) and air temperature (Fig. 1f) are at their peaks. As October 2010 had more precipitation only at the end of the month, for this study October 2010 is also considered as dry season. This is supported by the fact that the length and intensity of the dry season varies from year to year (da Rocha et al., 2009).

\subsection{Isoprenoid measurements and data analysis}

Ambient mixing ratio measurements of isoprene, total monoterpenes and total sesquiterpenes were carried out using 
a commercial high sensitivity proton-transfer reaction mass spectrometer (PTR-MS, IONICON, Austria). The PTR-MS was operated in standard conditions with a drift tube voltage of $600 \mathrm{~V}$ and drift tube pressure of $2.0 \mathrm{mbar}(\mathrm{E} / \mathrm{N}, 136 \mathrm{Td})$. During each PTR-MS measurement cycle, the following mass-to-charge ratios $(\mathrm{m} / z)$ were monitored: $21\left(\mathrm{H}_{3}^{18} \mathrm{O}^{+}\right)$, $32\left(\mathrm{O}_{2}^{+}\right), 37\left(\mathrm{H}_{2} \mathrm{O}-\mathrm{H}_{3} \mathrm{O}^{+}\right)$with a dwell time of $20 \mathrm{~ms}$ each; 69 (isoprene- $\mathrm{H}^{+}$), 137 (total monoterpenes- $\mathrm{H}^{+}$) and 205 (total sesquiterpenes- $\mathrm{H}^{+}$) with a dwell time of $5 \mathrm{~s}$ each (Jardine et al., 2011, 2012; Lindinger et al., 1998). The isoprenoid vertical profile was installed with 6 ambient air inlets at different tower heights $(2,11,17,24,30$, and $40 \mathrm{~m})$. Air was sequentially sampled during $10 \mathrm{~min}$ at each of the 6 heights, resulting in one complete profile every hour. Average mixing ratios were calculated for the daytime period (10:00-16:00, LT) and for the nighttime period (22:0004:00, LT). Calibration slope (m, ppbv/normalized counts per second (PTR-MS signal)) for isoprene, total monoterpenes, and total sesquiterpenes were obtained twice in the field using the dynamic solution injection technique (Jardine et al., 2010). Solutions of isoprene, $\alpha$-pinene, and $\beta$ caryophyllene standards ( $>95 \%$ purity, Merk) in $100 \mathrm{~mL}$ of cyclohexane were injected into the mixing vial at $0.5,1.0$, 2.0 , and $3.0 \mu \mathrm{Lmin}^{-1}$ (30 min each flow rate) with a constant dilution flow of 1.0 standard $\mathrm{L} \mathrm{min}^{-1}$ ultra high purity nitrogen passing through. The linearity of calibrations was significant, being $r^{2}$ of $0.92-0.97$ for isoprene, $r^{2}$ of 0.98 0.99 for $\alpha$-pinene, and $r^{2}$ of $0.90-098$ for $\beta$-caryophyllene. Sample air isoprenoid mixing ratios were calculated by multiplying the calibration slope by normalized counts per second (PTR-MS signal) (average of two calibration slopes). Calibration slopes obtained on October 2010 were within $10 \%$ relative to those from the calibration carried out in September 2010 (isoprene 7.2\%, $\alpha$-pinene $-8.2 \%$, and $\beta$ caryophyllene $-2.5 \%$ ). For 4-7 days before each isoprenoid profile measurement period, ultra high purity nitrogen was run into the inlet of the PTR-MS for $2 \mathrm{~h}$ in order to obtain the background signals. The limit of detection for isoprene was $0.14 \mathrm{ppbv}, 0.15 \mathrm{ppbv}$ for total monoterpenes and $0.1 \mathrm{ppbv}$ for total sesquiterpenes. More details about calibration and experimental design can be obtained in Jardine et al. (2011, 2012), in which a subset of these data are already described. While the previous study considered a subset of this data and time period (Jardine et al., 2011, 2012), this study examines the whole data set and focuses on seasonality of mixing ratios and fluxes. Also, this is the first study in central Amazonia that correlates long-term measurements of isoprenoids, light and temperature, and leaf phenology.

\subsection{Isoprenoid gradient flux, and modeled flux estimates - Model of Emissions of Gases and Aerosols from Nature (MEGAN 2.1)}

Fluxes of isoprene, total monoterpenes and total sesquiterpenes - for dry, dry-to-wet transition, and wet seasons - were estimated using the average daytime (10:00-14:00, LT) concentration vertical profile throughout the canopy and applying an inverse Lagrangian transport model (ILT) (Raupach, 1989; Nemitz et al., 2000; Karl et al., 2004, 2009). The source/sink distributions throughout the canopy were computed according to Eq. (1):

$\boldsymbol{C}-C_{\mathrm{Ref}}=\mathbf{D} \cdot \boldsymbol{S}$,

where $\boldsymbol{C}$ is the concentration $\left(\mathrm{g} \mathrm{m}^{-3}\right)$ vector for the six levels, $C_{\text {Ref }}$ is the concentration $\left(\mathrm{g} \mathrm{m}^{-3}\right)$ at reference height $(40 \mathrm{~m})$, $\mathbf{D}(\mathrm{m})$ is a dispersion matrix, and $\boldsymbol{S}\left(\mathrm{mg} \mathrm{m}^{-2} \mathrm{~h}^{-1}\right.$ layer $\left.^{-1}\right)$ is the resulting source/sink vector. D is expressed as a function of Lagrangian timescale and profiles of the standard deviation of the vertical wind speed $\left(\sigma_{\mathrm{w}}\right)$, which was normalized to friction velocity $\left(u^{*}\right)$. Integration over all source and sink terms $(\boldsymbol{S})$ yielded the canopy scale isoprenoid flux $\left(\mathrm{mg} \mathrm{m}^{-2} \mathrm{~h}^{-1}\right)$. To parameterize $\mathbf{D}$, we use the Lagrangian timescale (Tl) parameterized according to Raupach (1989) and the vertical profile of the standard deviation of the vertical wind speed scaled to measured friction velocity. The normalized turbulence profile was taken from turbulence measurements inside and above the canopy at this site recorded as part of AMAZE-08 (Amazonian Aerosol Characterization Experiment 2008) (Karl et al., 2009). The friction velocity was averaged for each season using daytime data (10:0014:00, LT) measured at a tower (K34 tower $-2^{\circ} 36^{\prime} 32.67^{\prime \prime} \mathrm{S}$, $60^{\circ} 12^{\prime} 33.48^{\prime \prime} \mathrm{W}$ ) that was $2 \mathrm{~km}$ away from the tower where isoprenoid profiles were measured (TT34 tower). The calculation of $\mathbf{D}$ was based on the far- and near-field approach described by Raupach (1989). As some model inputs (i.e., $\left.\sigma_{\mathrm{w}} / u^{*}\right)$ were obtained during the wet season at the TT34 tower in 2008 (Karl et al., 2009), changes in canopy structure between the two studies could potentially affect the results of this study. However, previous work carried out at the K34 tower showed that $u^{*}$ along with other averaged turbulence data have quite similar daytime values in both wet and dry seasons (Ahlm et al., 2010; Araujo et al., 2002).

Once fluxes from the isoprenoid vertical profiles were obtained by the ILT, they were compared with the isoprenoid fluxes estimated by the Model of Emissions of Gases and Aerosols from Nature (MEGAN 2.1). Isoprenoid emissions estimated by MEGAN 2.1 are based on a simple mechanistic model that takes into account the main processes driving variations in emissions (Guenther et al., 2012). As described by Guenther et al. (2012), the activity factor for isoprene, monoterpenes and sesquiterpenes $\left(\gamma_{\mathrm{i}}\right)$ considers the emission response to light $\left(\gamma_{\mathrm{P}}\right)$, temperature $\left(\gamma_{T}\right)$, leaf age $\left(\gamma_{\mathrm{A}}\right)$, soil moisture $\left(\gamma_{\mathrm{SM}}\right)$, leaf area index (LAI) and $\mathrm{CO}_{2}$ inhibition $\left(\gamma_{\mathrm{CO}_{2}}\right)$ according to Eq. (2):

$\gamma_{\mathrm{i}}=C_{\mathrm{CE}} \mathrm{LAI} \gamma_{\mathrm{P}} \gamma_{T} \gamma_{\mathrm{A}} \gamma_{\mathrm{SM}} \gamma_{\mathrm{CO}_{2}}$,

where $C_{\mathrm{CE}}$ is the canopy environment coefficient. For the present study, the canopy environment model of Guenther et al. (2006) was used. It has a $C_{\mathrm{CE}}$ of 0.57. MEGAN 2.1 
was run with variation in light and temperature and LAI. Leaf age of the foliage was estimated by the model based on changes in LAI. Soil moisture and $\mathrm{CO}_{2}$ inhibition activity factors were assigned a value $\gamma_{\mathrm{SM}}=1$ and $\gamma_{\mathrm{CO}_{2}}=1$, respectively, which assumes no variation in these parameters. More details about the model settings can be obtained in Guenther et al. (2012).

Photosynthetic photon flux density (PPFD) and air temperature for all model runs were obtained from the K34 tower measurement time series (The Large-Scale BiosphereAtmosphere Experiment - LBA). LAI inputs were obtained by satellite observations from NASA MODIS during August 2010 to January 2011. The level-4 LAI product is composited every 8 days at $1 \mathrm{~km}$ resolution on a sinusoidal grid (MODISNASA, 2015).

\subsection{Uncertainties associated with the ILT and BVOC emission modeling}

The main source of errors for applying the ILT is related to the parameterization of two combined effects: (1) vertical diffusion coefficient which is based on measured $\sigma(w) / u^{*}$ profiles, and (2) the Lagrangian dispersion time scale (Tl). Moreover, some uncertainties may be due to systematic error sources with respect to (3) chemical losses and (4) the number of source layers. The entire parameterization of combined effect (1) and (2) was tested using data from an earlier study (Karl et al., 2009, 2010), where a comparison with eddy covariance measurements was available. Taking the above conservative error assessment, the combined (effect 1 and 2) uncertainty is $+/-30 \%$.

To account for chemistry (effect 3 ) we used a simple modification of the diffusion coefficient based on Hamba (1993), relying on the fact that the chemical loss will mainly influence the far field of the parameterization. Based on estimated $\mathrm{OH}$ and measured $\mathrm{O}_{3}$ densities (Karl et al., 2009, 2010) calculated VOC fluxes were corrected accordingly. Due to low $\mathrm{OH}$ and $\mathrm{O}_{3}$ densities in the canopy $(<5 \times$ $10^{5}$ molecules $\mathrm{cm}^{-3}$ for $\mathrm{OH}$ and $<10 \mathrm{ppbv}$ for $\mathrm{O}_{3}$ ) the chemical lifetime for isoprene and monoterpenes is considered large compared to the mixing timescale, leading to a chemistry correction on the order of $<5 \%$ for isoprene and monoterpenes. This systematic error is included, but relies on an estimation of $\mathrm{OH}$ for isoprene. The overall uncertainty for isoprene is calculated as $0.3-4 \%$ by varying in-canopy $\mathrm{OH}$ densities between $5 \times 10^{5}$ and $5 \times$ $10^{6}$ molecules $\mathrm{cm}^{-3}$. It is noted that an in-canopy $\mathrm{OH}$ density of $5 \times 10^{6}$ molecules $\mathrm{cm}^{-3}$ is extremely unrealistic in such a dense canopy and only serves as a very conservative upper limit. Those assumptions were also considered for sesquiterpene flux estimates. However, a sensitivity test was carried out to show if the increasing ozone concentrations during the dry season could effectively affect sesquiterpene lifetime and then sesquiterpene flux estimates. For this test, sesquiterpene lifetime was changed in the ILT model using a range from $2 \mathrm{~min}$ to $8 \mathrm{~h}$ (upper limit used for isoprene and monoterpene flux estimates). The lower limit ( $2 \mathrm{~min}$ ) is based on the lifetime calculated for $\beta$-caryophyllene when it is exposed to $24 \mathrm{~h}$ average of $7 \times 10^{11}$ molecules $\mathrm{cm}^{-3}$ of ozone ( $\sim 30 \mathrm{ppb}$ ) (Atkinson and Arey, 2003). If all sesquiterpenes that occur in this site have similar reactivity with ozone as $\beta$ caryophyllene, the overall uncertainty for sesquiterpene flux estimates is calculated as up to $20 \%$ by varying sesquiterpene lifetime from $8 \mathrm{~h}$ to $2 \mathrm{~min}$. It is noted that when considering a lifetime range from $8 \mathrm{~h}$ to $10 \mathrm{~min}$, the uncertainty for sesquiterpene flux estimates is calculated as up to $4 \%$. The $20 \%$ of uncertainty may be important only during the dry season, when ozone mixing ratios can eventually reach 30 ppbv above canopy $(40 \mathrm{~m})$ around noontime.

We have also investigated the effect of (4) - the number of source layers. If the number of selected source layers is too small, systematic errors of the calculated integrated fluxes arise. We have investigated this effect and found that in the present case, 6 source layers are sufficient to capture $>90 \%$ of the flux. In the present setup, the ILT model does not converge for more than nine layers and the numerical solution becomes unstable. If the ILT model was initiated to only calculate two source layers, the integrated flux would be underestimated significantly (e.g. by up $50 \%$ ). With six source layers we estimate a systematic error of $<10 \%$ due to this effect. The combined effect of the systematic errors (3) and (4) is estimated to be 5-6\%.

Random errors of the ILT parameterization for effects (1) and (2) mostly relate to precision. Systematic errors (3) and (4) mostly relate to accuracy of the parameterization. While there could also be combined effects of random and small systematic errors, that are difficult to assess, we chose an overall conservative error estimate that should reflect precision and accuracy for effects (1) and (2), noting that the $30 \%$ should mostly relate to precision. All the uncertainties are 1 standard error.

With respect to uncertainties in model estimates, one of the first quantitative estimates of biogenic VOC emissions (Lamb et al., 1987) included an estimate of uncertainty of $210 \%$ based on the propagation of uncertainties in emission factors, emission algorithms, amount of biomass, and landuse distributions. This "factor of 3" uncertainty has continued to be used as a rough assessment of the uncertainty of biogenic VOC emission model estimates applied on regional scales. A more recent study (Hanna et al., 2005) attempted a comprehensive assessment of each model component and concluded that the $95 \%$ confidence range on the calculated uncertainty in isoprene emission was about 1 order of magnitude, while the calculated uncertainty for monoterpenes and other VOC was only $\pm 20 \%$. Guenther (2013) suggests that the Hanna et al. (2005) study assigns isoprene a higher uncertainty only because more is known about isoprene, and so there are more parameters, and that the lack of observations for quantifying the uncertainties associated with individual model parameters limits the usefulness of this uncer- 
tainty estimation approach and instead recommends evaluations that consider the results of model comparisons with canopy scale observations. These studies indicate that models tend to agree with observations within $\sim 30 \%$ for canopy scale studies with site specific parameters (Lamb et al., 1996) or for regional scale estimates with known land cover (Misztal et al., 2014) and differ by as much as a factor of 2 or more for other regional scale studies (Müller et al., 2008; Warneke et al., 2010).

\subsection{Canopy light penetration and leaf phenology}

The standard canopy environment model of MEGAN 2.1 was used to model light penetration into the canopy (Guenther et al., 2006). Model inputs included the above-canopy PAR measured (every $30 \mathrm{~min}$ ) at $50 \mathrm{~m}$ on the K34 tower for the whole period of isoprenoid measurements as well as the estimated surface area density of the canopy $\left(\mathrm{m}^{2} \mathrm{~m}^{-3}\right)$, with measurements carried out in March 2004 using a Light Detection and Ranging sensor (LIDAR) in a transect on the same plateau area of this study (Parker and Fitzjarrald, 2004).

The light penetration was modeled for five canopy layers distributed from the canopy top to the ground surface. The thickness of each of the five layers was determined based on the canopy surface area density estimated for every $50 \mathrm{~cm}$ from the ground surface to the top canopy (Parker and Fitzjarrald, 2004). The layers were distributed according to a Gaussian curve fit to the canopy surface area densities (from 0.5 to $48 \mathrm{~m}$ ). Light absorption was calculated as the difference in the model estimate of downward light at the top and bottom canopy levels. This light absorption corresponded to light that passed through the canopy vertically. Reflectance and scattering were not considered.

Leaf phenology was estimated based on the observation of leaf flushing events of the upper crown surfaces of 63 living trees around the K34 tower ( $\sim 2 \mathrm{~km}$ far of TT34 tower). For this approach, it is assumed that the leaf phenology of the upper crown surfaces of trees around both towers is similar. For the monitoring, a system of data acquisition and storage, based on a Stardot (model Netcam XL 3MP) camera with a $1024 \times 768$ resolution CMOS sensor, was installed at K34 tower, at $15-20 \mathrm{~m}$ above the canopy. The camera viewing angle was south azimuth, perpendicular to the solar transit, centered on $32^{\circ}$ of depression and pointing out to an area of plateau. Images were logged every $15 \mathrm{~s}$ to a passively cooled FitPC2i with heat-tolerant SSD drive. The whole system of data acquisition automatically rebooted after power outages. The images obtained by the camera covered approximately $66^{\circ}$ horizontally and $57^{\circ}$ vertically, fitting the forest canopy without including any area of sky in the image. The most distant trees in the image were located $150 \mathrm{~m}$ from the camera. The framework was fixed by monitoring the same 63 treetops over 4 months of observation (October 2010-January 2011). The analysis of images was based on the number of treetops that showed leaf flushing within 1 month. For this, one im- age was selected at every 6 days, and then grouped for each month of this study.

\subsection{Satellite-derived isoprene emission estimates}

Top-down isoprene emission estimates over the $0.5^{\circ}$ region around TT34 tower were obtained by using a gridbased source inversion scheme (Stavrakou et al., 2009) constrained by formaldehyde (HCHO) columns. $\mathrm{HCHO}$ is an intermediate product of the isoprene degradation process (e.g. Stavrakou et al., 2014). It is measured by UV-visible sensors, such as on the Global Ozone Monitoring Experiment (GOME-2)/MetOp satellite launched in 2006. The source inversion was performed using the global chemistry-transport model IMAGESv2 (Intermediate Model of Annual and Global Evolution of Species) run at a resolution of $2^{\circ} \times 2.5^{\circ}$ and 40 vertical levels from the surface to the lower stratosphere (Stavrakou et al., 2014, 2015). The priori isoprene emission inventory is taken from MEGAN-MOHYCAN-v2 (Stavrakou et al., 2014, http://tropo.aeronomie.be/models/ isoprene.htm), and includes updates regarding isoprene emission rates from Asian tropical forests. IMAGESv2 uses $\mathrm{HCHO}$ columns retrieved from GOME-2 sensor as topdown constraints and estimates the posterior biogenic isoprene emission on the global scale. Note that given the early morning (09:30) overpass time of the GOME-2 measurement, and the mostly delayed production of formaldehyde from isoprene oxidation, the top-down emission estimate is dependent on the ability of MEGAN to simulate the diurnal shape of isoprene emission and on the parameterization of chemical and physical processes affecting isoprene and its degradation products in IMAGESv2. For this study, we use daily $(24 \mathrm{~h}$ ) mean satellite-derived isoprene emissions derived from January 2010 to January 2011. More details can be found in Stavrakou et al. $(2009,2014,2015)$ and Bauwens et al. (2013).

\section{Results and discussion}

\subsection{Diurnal variation of isoprenoid mixing ratios}

Vertical profiles of isoprenoids were analyzed for daytime and nighttime for all the seasons considered in this study. Isoprene (Fig. 2a, b, c) and total monoterpenes (Fig. 2d, e, f) had higher mixing ratios during daytime (10:00-16:00, LT) than during nighttime (22:00-04:00, LT) for all seasons, supporting the findings that emissions of isoprene (Alves et al., 2014; Harley et al., 2004) and monoterpenes (Bracho-Nunez et al., 2013; Kuhn et al., 2002, 2004a; Jardine et al., 2015) from Amazonian plant species, at least at this site, are primarily light-dependent and stimulated by increasing temperature.

During daytime, isoprene had a maximum mixing ratio within the canopy. By comparison, at nighttime maximum values occurred above the canopy, and the vertical profiles were similar to those of nighttime air temperature (Fig. $2 \mathrm{j}$, 

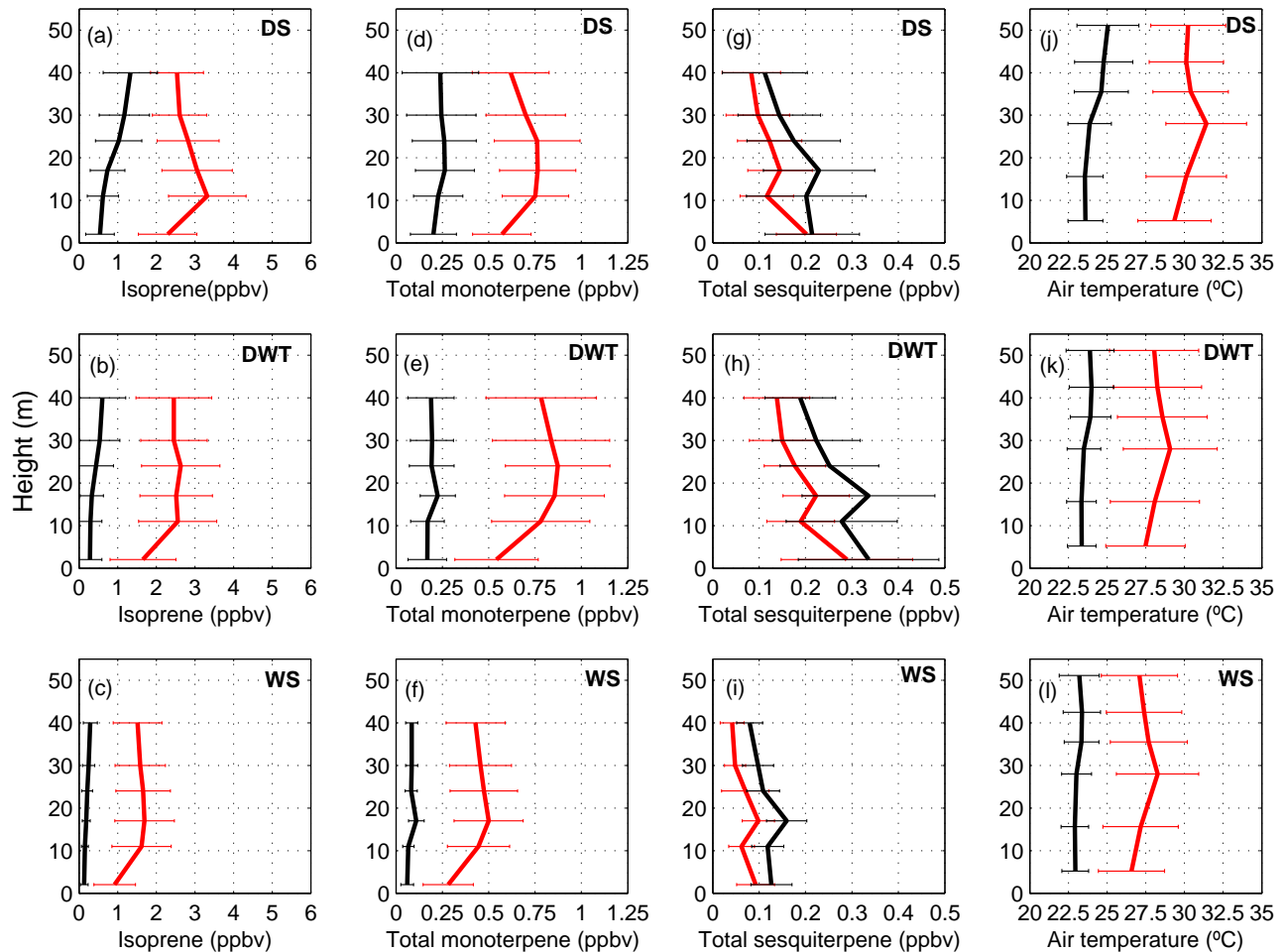

Daytime

- Nighttime

Figure 2. Daytime (10:00-16:00, LT) and nighttime (22:00-04:00, LT) average vertical profiles of isoprene (a, b, c), total monoterpenes (d, $\mathbf{e}, \mathbf{f})$, total sesquiterpenes $(\mathbf{g}, \mathbf{h}, \mathbf{i})$, and air temperature $(\mathbf{j}, \mathbf{k}, \mathbf{l})$ of the dry season (DS), the dry-to-wet transition season (DWT) and the wet season (WS). Error bars represent 1 standard deviation.

$\mathrm{k}, \mathrm{l})$. As isoprene is not emitted at night, this maximum nighttime abundance of isoprene above the canopy may be due to the daytime residual layer concentrations. In addition, isoprene lifetime increases during nighttime owing to the decrease of $\mathrm{OH}$ (hydroxyl radical) concentrations in the dark (Goldan et al., 1995) in light of the low concentrations of nitrogen oxides $\left(\mathrm{NO}_{x}\right)$ in Amazonia $(\leq 3 \mathrm{ppb}$ above the canopy during nighttime in the dry-to-wet transition season) (Andreae et al., 2002). Similar results found at another site in central Amazonia suggested that low isoprene concentrations near the ground after sunset could be due to deposition onto and consumption by surfaces (Yáñez-Serrano et al., 2015). Isoprene up-take in the soil has been suggested previously in central Amazonia (Silva, 2010), possibly because of isoprene microbial consumption (Cleveland and Yavitt, 1997; Gray et al., 2014). As with isoprene, higher mixing ratios of total monoterpenes were observed during daytime, indicating that they are light-dependent, which agrees with the evidence of recent photosynthetic origin of monoterpenes (Jardine et al., 2015; Loreto et al., 1996).

The vertical profile of total sesquiterpene mixing ratios differed from that of isoprene and total monoterpenes for all seasons. Total sesquiterpenes had higher mixing ratios near the ground and at the sub-canopy level $(17 \mathrm{~m})$ than above the canopy (Fig. $2 \mathrm{~g}, \mathrm{~h}, \mathrm{i})(P<0.05)$. Daytime and night- time vertical profiles had a similar shape, but total sesquiterpene mixing ratios were higher during the nighttime. Even though sesquiterpene emissions for some plant species are both light- and temperature-dependent (Duhl et al., 2008), results reported here indicate that sesquiterpene emissions are not strongly light-dependent in this site, suggesting that their daily variation is driven primarily by temperature. Since some studies have shown that sesquiterpenes are found in the essential oil stored in Amazonian forest trees (e.g. Lima et al., 2005), emissions from these storage structures would not be expected to be light-dependent. In contrast, the monoterpenes, while also present in the essential oil of Amazonian trees (e.g. Fidelis et al., 2012; Lima et al., 2005), appear to be dominated by emissions that occur with no storage (e.g. Loreto et al., 1996; Jardine et al., 2015), similar to isoprene emission processes. Another reason for the higher total sesquiterpene mixing ratios at nighttime might be because of the reduction of oxidative reactions owing to the decrease of $\mathrm{OH}$ concentrations in the dark (Goldan et al., 1995) and low concentrations of nitrogen oxides $\left(\mathrm{NO}_{x}\right)$ (Andreae et al., 2002), ozone, and nitrate $\left(\mathrm{NO}_{3}\right)$ in Amazonia (Martin et al., 2010). In addition, ozonolysis of sesquiterpenes during daytime can reduce ambient sesquiterpene concentrations, as previously reported for a subset of these data (Jardine et al., 2011). With daytime ozone mixing ratios up to $40 \mathrm{ppbv}$ 
(a)
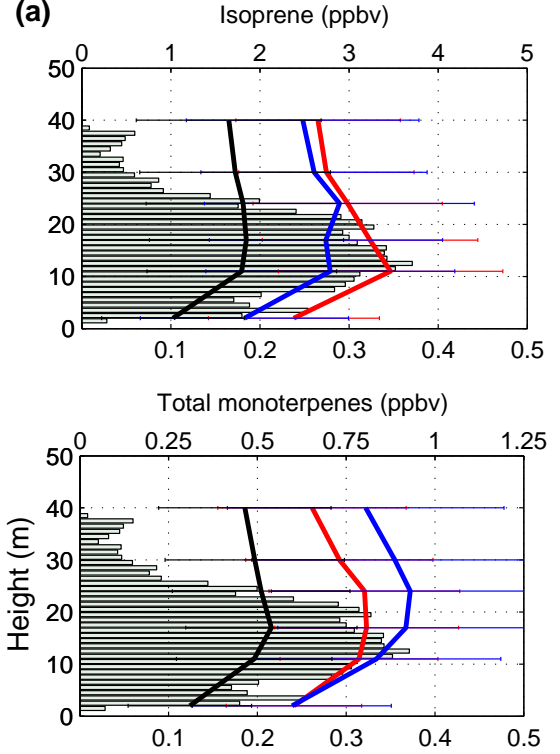

Total sesquiterpenes (ppbv)

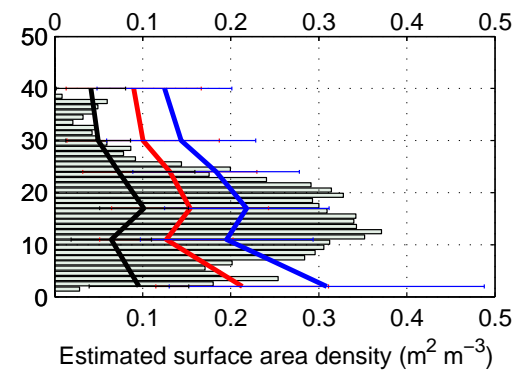

(b)

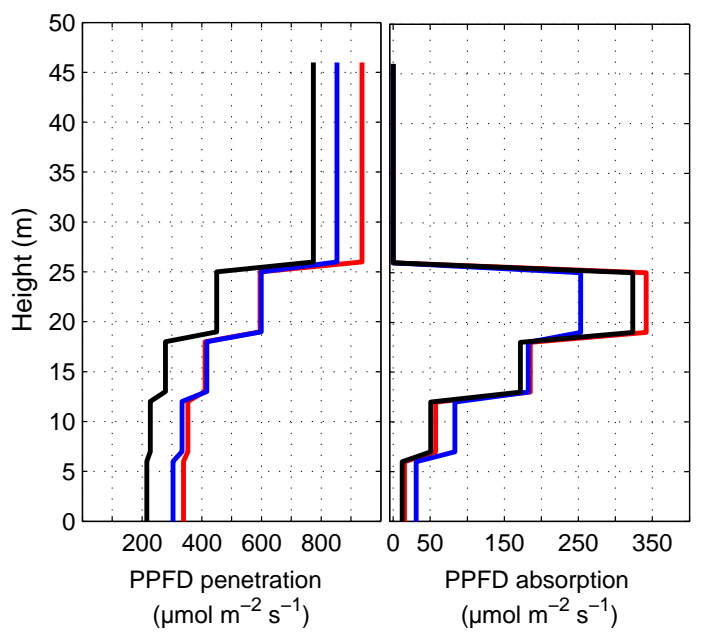

(c)

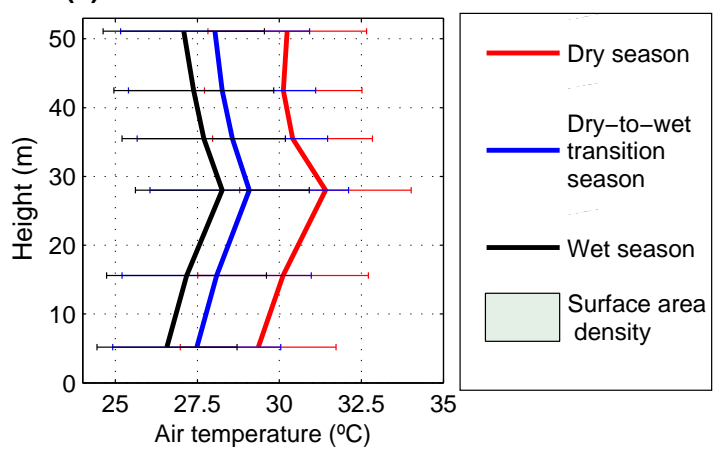

Figure 3. Daytime (10:00-16:00, LT) vertical profiles of mixing ratios of isoprene, total monoterpenes and total sesquiterpenes from the dry season to the wet season; and estimated surface area density of the canopy at this study site (ground-based measurements carried out in March 2004 using LIDAR - Light Detection And Ranging) (Parker and Fitzjarrald, 2004) (a). Vertical profile of photosynthetic photon flux density (PPFD) penetration and absorption by the canopy from the dry season to the wet season modeled by MEGAN 2.1 (b). Daytime (10:00-16:00, LT) air temperature profiles from dry season to wet season measured at K34 tower (c). In Fig. 1a the top and the bottom $x$ axis represent isoprenoid mixing ratios and estimated surface area density of the canopy, respectively. Error bars represent 1 standard deviation.

(40 m) during the dry season, sesquiterpene lifetime with respect to ozonolysis above the canopy $(40 \mathrm{~m})$ can be $2 \mathrm{~min}$ during the daytime and $5 \mathrm{~min}$ during the nighttime (Jardine et al., 2011). Additionally, sesquiterpene concentrations can build up near the surface, because during nighttime the storage in the forest dominates (80-90\%) and is significantly larger than the turbulent flux (Karl et al., 2004).

\subsection{Seasonal variation on isoprenoid mixing ratios and emissions}

Vertical profiles of isoprene had higher mean mixing ratios in the dry season, followed by the dry-to-wet transition season and wet season (top panel of Fig. 3a). The reduction of isoprene mixing ratios from the dry season to dry-to-wet transition season was up to $20 \%$ and from dry season to wet season was up to $65 \%$. During the dry season, the higher mixing ratios and emissions of isoprene have been attributed to the higher insolation and higher temperatures compared to the wet season and, for this reason, higher isoprene concentrations at the top of the canopy are expected. Nevertheless, in contrast to the observations of Yañez-Serrano et al. (2015), who reported maximum daytime mixing ratios of isoprene at the top of the canopy for both dry and wet seasons, this study showed the highest isoprene mixing ratios inside the canopy $(11 \mathrm{~m})$ during the dry season, with this maximum moving to the upper canopy during the dry-to-wet transition season (24 m).

Isoprene emissions inferred from concentration vertical profiles were estimated to be highest in the sub-canopy $(16 \mathrm{~m})$ during the dry season and in the upper canopy $(28 \mathrm{~m})$ during the dry-to-wet transition season and the wet season (Fig. 4a). Even though there were differences in which layer was the highest emitter of isoprene within the canopy, mean isoprene emissions into the atmosphere were about the 
(a)

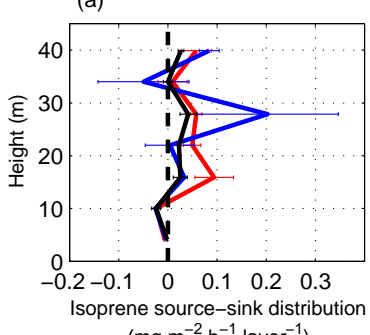

(d) $\left(\mathrm{mg} \mathrm{m}^{-2} \mathrm{~h}^{-1}\right.$ layer $\left.^{-1}\right)$

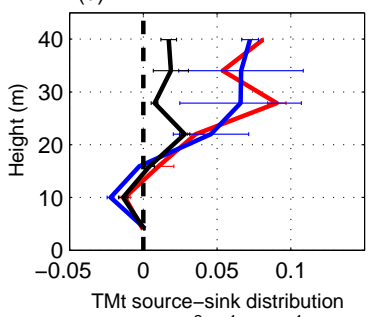

(g) $\left(\mathrm{mg} \mathrm{m}^{-2} \mathrm{~h}^{-1}\right.$ layer $\left.^{-1}\right)$

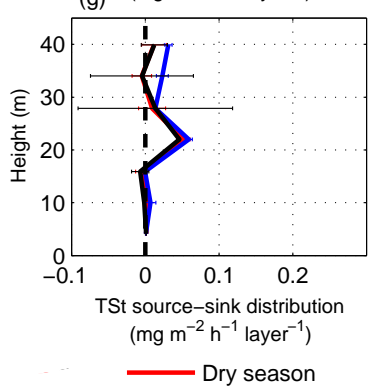

(b)

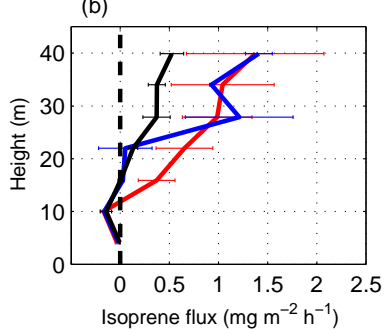

(e)
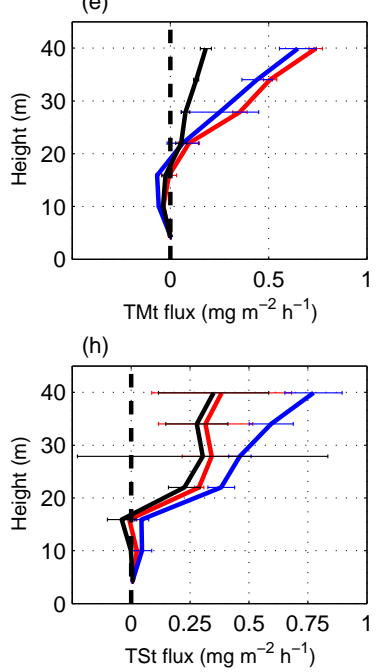

Dry-to-wet transition season

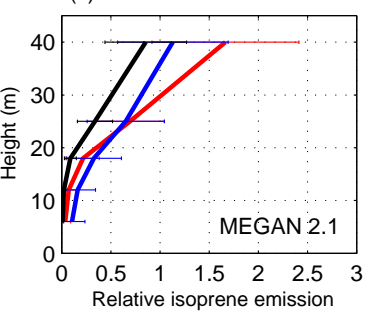

(f)
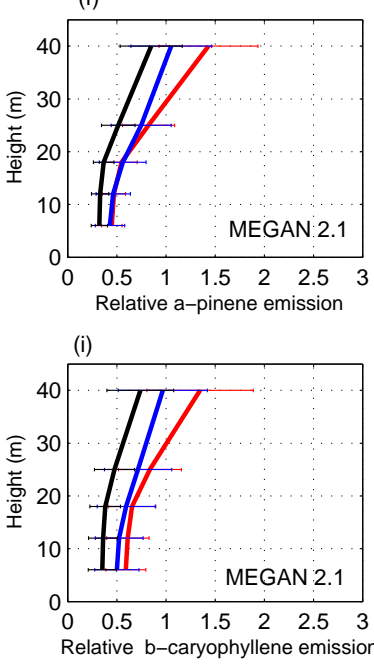

Figure 4. Daytime (10:00-14:00, LT) source-sink distribution inside and above the canopy, cumulative flux estimation, and relative emission modeled by MEGAN 2.1 of isoprene $(\mathbf{a}, \mathbf{b}, \mathbf{c})$, total monoterpenes (TMt) $(\mathbf{d}, \mathbf{e}, \mathbf{f})$ and total sesquiterpenes $(\mathrm{TSt})(\mathbf{g}, \mathbf{h}, \mathbf{i})$ from the dry season to the wet season. Error bars represent 1 standard deviation.

same for the dry season and the dry-to-wet transition season ( $1.37 \pm 0.7$ and $1.41 \pm 0.1 \mathrm{mg} \mathrm{m}^{-2} \mathrm{~h}^{-1}$, respectively). Both of these seasons had higher isoprene emissions than during the wet season $\left(0.52 \pm 0.1 \mathrm{mg} \mathrm{m}^{-2} \mathrm{~h}^{-1}\right)$ (Fig. $\left.4 \mathrm{~b}\right)$.

The maximum absorption of PPFD by canopy, calculated based on PPFD penetration profile modeled by the standard MEGAN 2.1 canopy environment model, occurred right above the maximum of estimated surface area density of the canopy, with the absorption of PPFD being higher during the dry season, followed by the wet season and the dry-to-wet transition season (Fig. 3b). This maximum PPFD absorption at the upper canopy agreed with the maximum of isoprene mixing ratios (top panel of Fig. 3a) and emissions (Fig. 4a) during the dry-to-wet transition season. It differed, however, when compared to peaks of isoprene mixing ratios and emissions during the dry season and the wet season.

One reason for this difference could be the isoprene oxidation in the atmosphere and within plant, especially at the top of the canopy. During the dry season the ratio of methyl vinyl ketone + methacrolein + hydroperoxides (MVK + MAC + ISOPOOH) (Liu et al., 2013) to isoprene was higher compared to the dry-to-wet transition and the wet season (data not shown). This higher ratio may indicate an increased oxidative capacity of the atmosphere during the dry season. Moreover, a small source of MVK + MAC + ISOPOOH was observed at the top of the canopy (Jardine et al., 2012). Under conditions of high abiotic stress, as can occur in the dry season, elevated isoprene oxidation rates in plants can be observed and isoprene oxidation products might be directly emitted by plants (Jardine et al., 2012).

Another important factor might be leaf phenology and/or leaf demography. Different tree species have different isoprene emissions rates, and these rates depend upon the leaf ontogenetic stage. Isoprene emitters can flush at different canopy levels seasonally, and changes in within-canopy isoprene vertical profiles would be expected as a result. Moreover, as more leaf flushing was observed at the upper canopy during the wet-to-dry transition and early dry season, this caused leaves in the age group of 3-8 months to reach the highest abundance in late dry season and early wet season (Nelson et al., 2014). The period with the high abundance of leaves in this age group is coincident with the period when gross ecosystem productivity and landscape-scale photosynthetic capacity is most efficient (Restrepo-Coupe et 
al., 2013). Here, results show maximum isoprene emission at the upper canopy during the dry-to-wet transition season (Fig. 4a), which is coincident with the period of high abundance of healthy efficient leaves at the canopy top (Nelson et al., 2014) and also coincident with the maximum isoprene emission shown in young mature leaves in the dry-to-wet transition season (Alves et al., 2014). Similarly, higher isoprene emissions during the late dry season have also been related to the increase of active biomass in southern Amazonia (Kesselmeier et al., 2002; Kuhn et al., 2004a, b).

Although the isoprene mixing ratios reported here are within the range of previously reported values in central Amazonia for the dry season and the dry-to-wet transition season (Greenberg and Zimmerman, 1984; Rasmussen and Khalil, 1988; Zimmerman et al., 1988) and for the wet season (Yáñez-Serrano et al., 2015), these results are the lowest observed fluxes of isoprene to atmosphere reported for the Amazonia. However, this could be due to features associated with the site of this study, such as the relatively open canopy caused by the proximity to a dirt road and perhaps a relatively low fraction of isoprene emitting species. Isoprene fluxes measured previously at the same tower site during the wet season were similar (Karl et al., 2009).

Total monoterpenes also showed a strong seasonal variation with maximum mixing ratios during the dry-to-wet season, followed by the dry season and the wet season (middle panel of Fig. 3a). Taking mixing ratios of the dry-towet transition season as a reference, total monoterpene mixing ratios showed an increase of up to $20 \%$ from the dry season to the dry-to-wet transition season, and a decrease of up to $50 \%$ from the dry-to-wet transition season to the wet season. Although total monoterpene mixing ratios were somewhat higher in the dry-to-wet transition season than during the dry season, total monoterpene fluxes inferred by the vertical profiles were slightly higher during the dry season $\left(1.47 \pm 0.06 \mathrm{mg} \mathrm{m}^{-2} \mathrm{~h}^{-1}\right)$ compared to the dry-to-wet season $\left(1.29 \pm 0.2 \mathrm{mg} \mathrm{m}^{-2} \mathrm{~h}^{-1}\right)$ (Fig. 4e), indicating that the production is higher in the dry season and losses are also higher, leading to lower mixing ratios. In comparison, emissions from these two seasons were considerably higher than during the wet season $\left(0.36 \pm 0.05 \mathrm{mg} \mathrm{m}^{-2} \mathrm{~h}^{-1}\right)$ (Fig. 4e). This again indicates that higher insolation and air temperature during the dry season and dry-to-wet transition season compared to the wet season increased the atmospheric concentrations of monoterpenes and, considering the enhanced ozone mixing ratios during the dry season, this may influence the seasonal pattern in monoterpene ozonolysis loss rates (Jardine et al., 2015). These results agree with branch level measurements that showed higher monoterpene emissions during the dry-to-wet transition season compared to the wet-to-dry transition season (Kuhn et al., 2004a). However, results reported here differ from those presented for the southern Amazonia, where monoterpene mixing ratios were higher during the wet season than during the dry season (Kesselmeier et al., 2002). Although only a few studies have been carried out with the objective of investigating monoterpene seasonal variations, factors other than light and temperature might influence monoterpene emissions from vegetation, including the oxidative capacity of the atmosphere and leaf phenology (Kesselmeier et al., 2002; Kuhn et al., 2004a).

Total monoterpene mixing ratios and fluxes, during the dry season and the dry-to-wet transition season, were similar to values reported for other sites in central Amazonia (Karl et al., 2007; Yáñez-Serrano et al., 2015). However, the monoterpene comparison of reported studies is a difficult endeavor given that some techniques measured total monoterpenes and others measured some specific monoterpene compounds, and also because monoterpene fragmentation during measurements (PTR-MS) could affect the absolute values of these compounds. Therefore, further efforts are needed in order to characterize the seasonal abundance and the seasonal species-specific composition of monoterpenes in the Amazonia.

Average vertical profiles of total sesquiterpene mixing ratios were higher in the dry-to-wet transition season, followed by the dry season and the wet season (bottom panel of Fig. 3a). Taking mixing ratios of the dry-to-wet transition season as a reference, total sesquiterpene mixing ratios increased up to $30 \%$ from the dry season to the dry-to-wet transition season and decreased by up to $55 \%$ from the dry-towet transition season to the wet season. During the dry season and the dry-to-wet transition season, the maximum total sesquiterpene mixing ratios were observed near the ground. During the wet season, the maximum mixing ratio was at $17 \mathrm{~m}$ (sub-canopy). According to Jardine et al. (2011), during the daytime many sesquiterpenes (46-61\% by mass) are rapidly oxidized by ozone as they undergo within-canopy ozonolysis and contribute to the scarcity of total sesquiterpenes above and near the top of the canopy. Considering that higher insolation and also higher ozone concentrations were observed during the dry season (ozone daily average of $\sim 23$ and $\sim 10 \mathrm{ppbv}$ at $40 \mathrm{~m}$ in the dry and wet seasons, respectively), an important fraction of the sesquiterpenes emitted by vegetation could be rapidly oxidized by ozone, leading to significantly lower mixing ratios of total sesquiterpene during the dry season (Jardine et al., 2011), which creates a need to account for sesquiterpene oxidation within the canopy when calculating emission rates.

Another potential reason for higher mixing ratios of total sesquiterpenes near the ground is that emission could come from surface sources including litter, roots and soil microbes and fungi. Silva (2010) presented surface BVOC emissions at this site, and the results suggested that the litter decomposition could be an important source of sesquiterpenes to the atmosphere. Litter production is higher during the dry than during the wet season (Luizão, 1989), which could lead to higher amounts of litter at the end of the dry season. Rain starting to increase in the dry-to-wet transition could contribute to more decomposition of the litter storage, which can potentially increase sesquiterpene emissions during the processes 


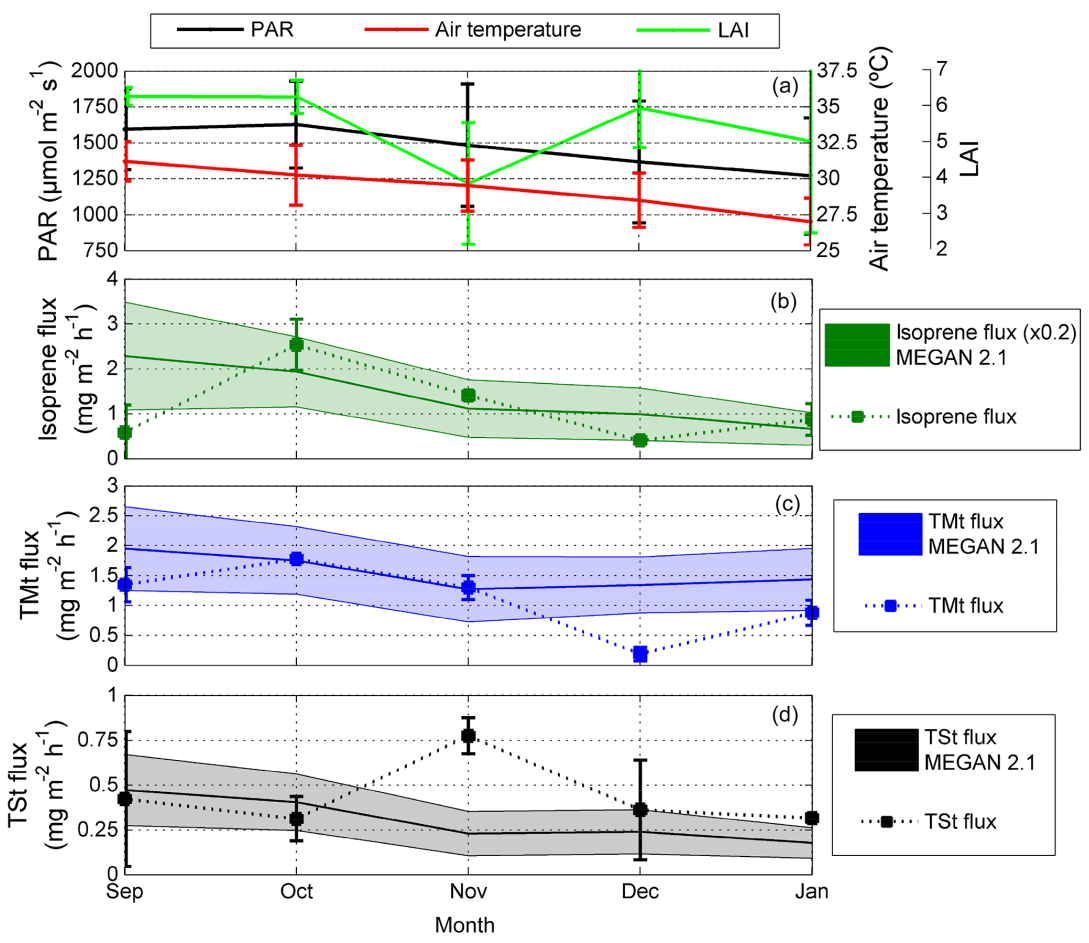

Figure 5. Monthly averages of air temperature and PAR (measured at K34 tower during 10:00-14:00, LT), and LAI (MODIS, 8-day observations) (a). Monthly averages of fluxes of isoprene (b), total monoterpenes (TMt) (c) and total sesquiterpenes (TSt) (d). Flux based on in situ PTR-MS measurements (inverse Lagrangian transport model - estimates for 10:00-14:00, LT, at TT34 tower) are represented by solid squares and 1 standard deviation; fluxes modeled by MEGAN 2.1 (estimates for 10:00-14:00, LT) are shown by solid lines and filled areas that represent 1 standard deviation. Isoprene flux modeled by MEGAN 2.1 in (b) were divided by five. Error bars represent 1 standard deviation.

of decomposition of dead organic matter. Although the ecological functional role of these sesquiterpenes is not known, abiotic emissions from the litter have a specific signature that can be similar to the concentration profile in the green leaf content (Austin et al., 2014) and in sufficient concentration BVOCs can have the capacity of attracting and repelling soil organisms to a specific location (Austin et al., 2014). Therefore, higher sesquiterpene emissions from the litter could be a signal to the fauna related to the decomposition process and represent an important step of the biogeochemical cycling.

In contrast to the mixing ratios, the source-sink distribution analysis made from the vertical profiles of total sesquiterpenes indicated that the main source of these compounds is the canopy ( $24 \mathrm{~m}$ ) (Fig. $4 \mathrm{~g}$ ), and the integration of sources and sinks showed that the highest total sesquiterpene emission rates going into the atmosphere was during the dry-to-wet transition season $\left(0.77 \pm 0.1 \mathrm{mg} \mathrm{m}^{-2} \mathrm{~h}^{-1}\right)$, followed by the dry season $\left(0.38 \pm 0.2 \mathrm{mg} \mathrm{m}^{-2} \mathrm{~h}^{-1}\right)$, and the wet season $\left(0.34 \pm 0.2 \mathrm{mg} \mathrm{m}^{-2} \mathrm{~h}^{-1}\right)$ (Fig. 4h). However, although Nemitz et al. (2000) have suggested that limitations on the $\sigma_{\mathrm{w}} / u^{*}$ parameterization close to the ground do not affect the net flux above the canopy, here we strongly suggest future studies focus on better characterizing the turbulence and oxidation processes at this site, in order to verify the source- sink distribution of sesquiterpenes within the canopy and the emissions from the canopy to atmosphere. This should include speciated sesquiterpene measurements in order to account for their specific reactivity with ozone and other oxidants.

Relative emissions can be calculated as emissions normalized to standard conditions of above-canopy PAR of $1500 \mu \mathrm{mol} \mathrm{m}^{-2} \mathrm{~s}^{-1}$ and temperature of $30^{\circ} \mathrm{C}$. Based only on light, temperature and LAI variation, relative emissions estimated by MEGAN 2.1 were maximum during the dry season for isoprene, $\alpha$-pinene, and $\beta$-caryophyllene (Fig. 4c, $\mathrm{f}, \mathrm{i})$, when the highest light and temperature were observed. This prediction differs from the ILT flux estimates (Fig. 4b, $\mathrm{e}, \mathrm{h}$ ), which showed similar emissions between the dry and the dry-to-wet season for isoprene and total monoterpenes and maximum emission during the dry-to-wet season for total sesquiterpenes. The overall uncertainties related to ILT flux was calculated as $\pm 36 \%$ and MEGAN estimates are considered to be in agreement with observations when they are within $\sim 30 \%$. However, more observation studies are needed in order to evaluate the degree of observationmodeling agreement and to improve model approaches, especially for total monoterpenes and total sesquiterpenes, which could present larger uncertainties due to the lack of infor- 


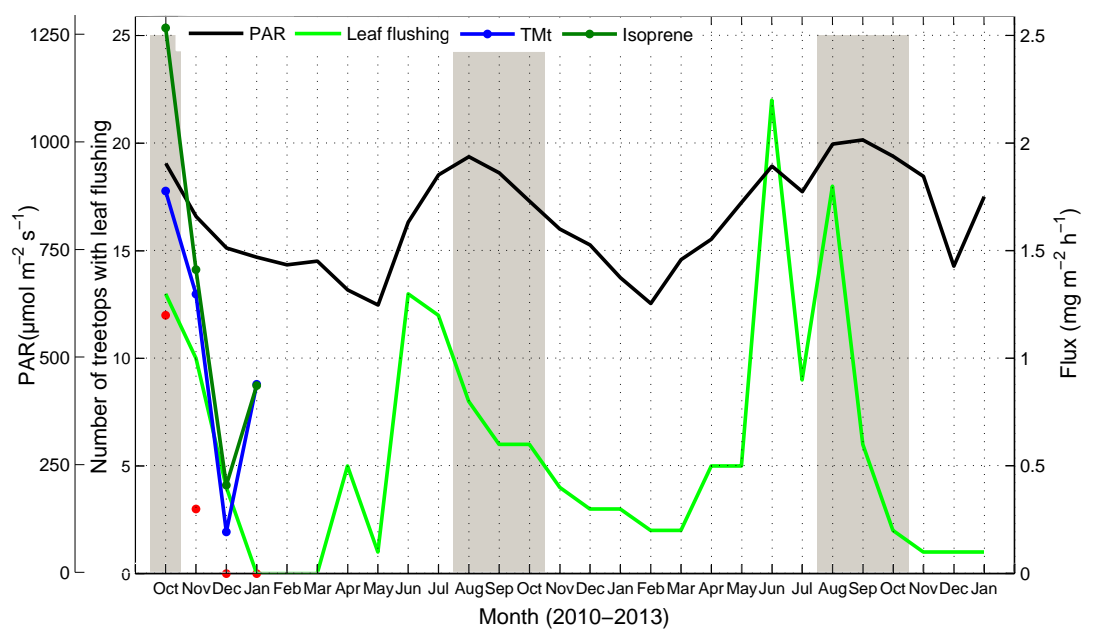

Figure 6. Estimated monthly leaf flushing (light green line) (Tavares, 2013), and monthly average of PAR measured from October 2010 to January 2013 at K34 tower (06:00-18:00, LT) (black line). For the period of this study, leaf flushing is also represented by the analysis of canopy images for every 6 days from October 2010 to January 2011 (red circles). Monthly averages of fluxes of isoprene (dark green line) and total monoterpenes (blue line) (estimated for 10:00-14:00, LT, at TT34 tower). Grey areas represent the period of the dry season.

mation about atmospheric concentrations and reactivity of monoterpene and sesquiterpene chemical species in Amazonia.

To compare the seasonal variation of isoprenoid emissions with changes in environmental (light and temperature) and biological (LAI) factors in more detail, monthly fluxes of isoprenoids were compared to PAR at $51 \mathrm{~m}$, air temperature at $51 \mathrm{~m}$, and LAI (satellite observations - MODIS) (Fig. 5). The highest fluxes of isoprene and total monoterpene were observed when PAR was at its highest (October 2010) (Fig. 5b, c), and when there is high abundance of healthy efficient leaves (Nelson et al., 2014). The similarity in the behavior of isoprene and monoterpene emissions is supported by the evidence of the photosynthetic origin of monoterpenes (Jardine et al., 2015; Loreto et al., 1996). Interestingly, in September 2010 total monoterpene emissions were higher than isoprene emissions. This could be related to the higher source of monoterpenes in the upper canopy compared to isoprene during this month. When there are more young leaves at the upper canopy during the first half of the dry season (Nelson et al., 2014), high emissions of monoterpenes can be expected. Total sesquiterpene fluxes tracked neither PAR nor air temperature, having the highest emission when PAR and air temperature were decreasing (November 2010) (Fig. 5d).

Predictions from MEGAN 2.1 again differed from measured emissions (Fig. 5b, c, d), showing a reduction in emissions from September 2010 to January 2011. Major quantitative differences between ILT and MEGAN estimates can be shown for isoprene in September, when ILT estimates represented only $4 \%$ of the MEGAN estimates; for total monoterpenes in December, when ILT estimates accounted for $14 \%$ of the MEGAN estimates; and for total sesquiterpenes in November, when ILT estimates were $232 \%$ higher than MEGAN estimates. These differences may be related to local effects, especially leaf phenology and changes in the atmospheric oxidative capacity over the seasons. In order to evaluate the potential effect of leaf phenology on emissions, leaf flushing, PAR, isoprene and total monoterpenes at canopy scale were compared in Fig. 6. They closely tracked each other during the 4 months of measurements. For the period of this study, the analysis of canopy images for every 6 days from October 2010 to January 2011 showed a decrease in leaf flushing from the end of the dry season to the wet season, which was similar to the decrease of isoprene and total monoterpene emissions and PAR. Results from 28 months (October 2010-January 2013) of canopy imaging have shown that the highest number of treetops with leaf flushing occurred during the wet-to-dry transition season (June-July), accounting for $35-50 \%$ of treetops with leaf flushing, followed by a subsequent decrease until the end of the wet season (Tavares, 2013) (Fig. 6). Correspondingly, the results of the present study suggest that lowest emissions might be expected in the June-July time period. These results agree with those presented by Barkley et al. (2009) using remote sensing, suggesting that seasonal changes in isoprene emissions may be strongly affected by leaf phenology in the Amazonia.

In order to verify if the seasonal trend of the isoprene emissions observed in this study can also be observed in a $0.5^{\circ}$ grid cell around TT34 tower, isoprene emissions estimated based on tower vertical profile concentrations are compared with estimates constrained by satellite measurements of $\mathrm{HCHO}$ in Fig. 7. The top-down estimates have a seasonal cycle that is similar to the bottom-up approach. Compared to the dry season, fluxes decrease by $40 \%$ during the wet and the wet-to-dry transition season from April to 


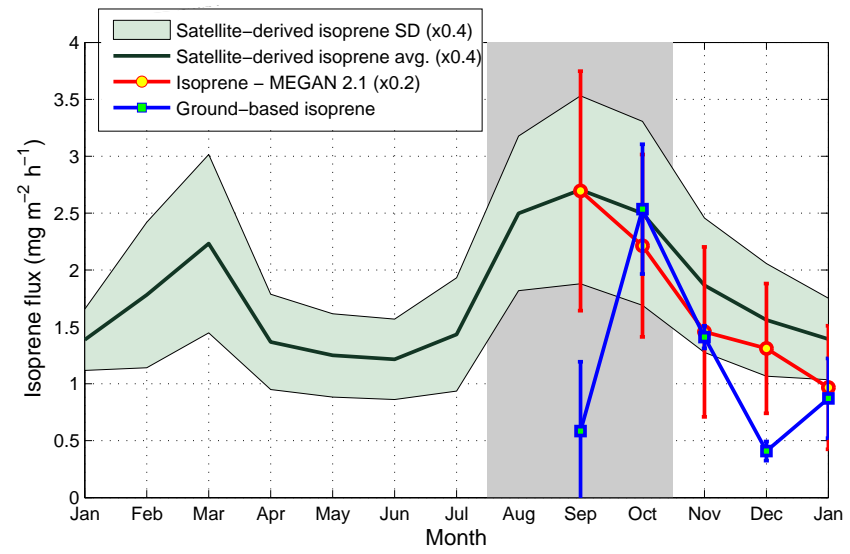

Figure 7. Comparison of monthly isoprene emissions based on insitu PTR-MS measurements (inverse Lagrangian transport model) and satellite-derived estimates and MEGAN 2.1 estimates. Satellitederived estimates are from January 2010 to January 2011, and ground-based estimates are from September 2010 to January 2011. Satellite-derived and MEGAN 2.1 estimates were divided by 2.5 and 5, respectively. Grey area represents the period of the dry season. Error bars represent 1 standard deviation.

July (Stavrakou et al., 2015), in qualitative agreement with the conclusions drawn in Barkley et al. (2009). The inferred dry season isoprene flux is about twice that of the wet-todry season. It peaks in September and gradually drops from October to January (Fig. 7), as a result of decreasing temperature and solar radiation, affecting the oxidation of isoprene leading to $\mathrm{HCHO}$ formation. The ground-based estimates exhibit a much stronger month-to-month variation, with flux estimates of 5 times higher in October compared to September and December. The small increase of the flux between December and January is not observed by the satellite observations. Despite these differences, partly due to reduced representativeness when comparing local measurements with flux estimates from a $0.5^{\circ}$ grid cell, this comparison shows that both large (satellite) and small (ground-based) scales agree that there are enhanced isoprene emissions during the dry season followed by a reduction towards the wet season.

The results reported here are associated with a small footprint area. This together with the huge biodiversity of tropical rainforests makes it impossible to generalize these results to the regional scale. Moreover, although some previous reports have suggested significant seasonal variations of BVOCs based on in situ measurements in different subregions of Amazonia, when those investigations (summarized in Table 1) and this study were compared, high variability is apparent among values of mixing ratios and fluxes. This variability could be due to the following: (1) different methodologies, (2) sampling in different seasons, (3) sampling in different regions (e.g., south, north, west, eastern Amazonia), (4) sampling in different ecotones of the same region, (5) different statistical analyses, and (6) perhaps due to small data sets that are not statistically significant to characterize emissions of a specific site.

\subsection{Comparison with model predictions of seasonal isoprenoid emissions in Amazonia}

Although the canopy scale isoprenoid emission measurements presented here differed from those modeled by MEGAN 2.1 (Figs. 4, 5), which assume that variations are driven primarily by light, temperature and leaf area, in terms of seasonal variation, MEGAN 2.1 estimates of isoprene emission agreed fairly well with the satellite-derived isoprene emission, which suggests that other factors at this site could influence isoprene emissions locally. As already mentioned, leaf phenology may cause important effects on local emissions. As MEGAN 2.1 was driven with local variations in PAR and air temperature, and with regional variations of LAI (satellite observations at $1 \mathrm{~km}$ resolution), this regional variation in LAI may not represent the local effect of LAI variation on local emissions, since vegetation in Amazonia is phenologically distinct due to the huge biodiversity of this ecosystem (Silva et al., 2013). Furthermore, as the canopy structure might vary seasonally due to leaf phenology/demography, the pattern of light penetration/absorption and then leaf temperature may change as well; thus, this, together with the differences in emissions among species and among leaf ontogenetic stages, could have an important impact on seasonal changes of local emissions.

Besides the effects of light, temperature and leaf phenology/demography, some efforts have been made to include effects of $\mathrm{CO}_{2}$ variation (Arneth et al., 2007; Guenther et al., 2012) as well as the link between photosynthesis and emission (Grote et al., 2014; Morfopoulos et al., 2013, 2014; Unger et al., 2013) into isoprene emission models at regional and global scales. However, the current regional and global BVOC emission models predict much smaller seasonal variations (Guenther et al., 2006, 2012; Müller et al., 2008; Unger et al., 2013) compared to the measurements in Amazonia (Table 1). Furthermore, satellite observations indicate that the current understanding of the processes controlling seasonal variations is insufficient, and models do not simulate the unexpected shutdown of isoprene emission in the Amazonia during the wet-to-dry transition season (Barkley et al., 2009).

Many recently published studies have used the MEGAN model and the majority have focused on improving our understanding of isoprene emissions. Although other models have been developed on the basis of known biochemical processes (Grote et al., 2014; Morfopoulos et al., 2014; Unger et al., 2013), the general framework and processes simulated are similar. The biochemical basis of isoprene production and release must be further understood to develop mechanistic explanations for variation in isoprene emission (Monson et al., 2012), which may reduce uncertainties associated with the responses to environmental factors. 
Seasonal variation of isoprene emissions might be explained by the change in energy supply from photosynthesis throughout the seasons (e.g. Grote et al., 2014). This is supported by the generally strong correlation between isoprene emission and gross photosynthetic capacity reported for Amazonian tree species (Kuhn et al., 2004b), and by the fact that higher demography of healthy efficient leaves (Nelson et al., 2014) coincides with the period of most efficient landscape-scale photosynthesis and photosynthetic capacity (Restrepo-Coupe et al., 2013). However, more measurements are needed to examine this relationship which should follow PAR variation. Additionally, since canopy structure may explain some variation in biomass growth over tropical landscapes due to differences in the pattern of light penetration and absorption by the canopies (Stark et al., 2012), measurements of canopy structure may also help to explain some of the differences in isoprenoid emissions among the Amazonian sub-regions.

Therefore, at least for the Amazonian rainforest, models currently do not fully capture seasonal variations in isoprenoid emissions, especially for monoterpenes and sesquiterpenes, which are less investigated compared to isoprene. The scarcity of measurements in Amazonia prevents the development and evaluation of accurate model approaches. Thus, this study strongly encourages future in situ measurements in Amazonia, including at leaf level, in order to verify changes driven by seasonal variations in leaf area, leaf age, phenology and emission response to soil moisture, and the short-term and long-term temperature and light environment.

\section{Summary and conclusions}

In this study, we present the first in situ measurements that show a seasonal trend in isoprenoid emissions for a primary rainforest of central Amazonia. Isoprenoid emissions peak at the end of the dry season and at the dry-to-wet transition season. Under conditions of high insolation and high temperatures joined together with the high demography of photosynthetically efficient leaves (Caldararu et al., 2012; Myneni et al., 2007; Nelson et al., 2014; Samanta et al., 2012), isoprenoid metabolic pathways may experience more favorable conditions for synthesizing these compounds in the dry season and the dry-to-wet transition season. This is especially for the case of isoprene and monoterpenes, which are lightand temperature-dependent and are affected by the recent production of photosynthetic substrates.

Although some studies have suggested that there are no seasonal variations in canopy structure and greenness in Amazonia (e.g. Morton et al., 2014), results reported here present a seasonal variation of leaf flushing and suggest maximum leaf demography in the late dry season, which generally agrees with the assumption that a "greenup" during the dry season in Amazonia may drive increasing iso- prene emissions as suggested by satellite retrievals (Barkley et al., 2009). Moreover, this study also suggests that seasonal changes in the atmospheric oxidative capacity could have an important impact on the seasonality of at least some isoprenoid concentrations and above canopy emissions, especially for sesquiterpenes. Their quantification is challenged by rapid atmospheric chemical reactions catalyzed by high insolation and higher ozone concentrations in the dry season.

MEGAN 2.1 estimates did not fully capture the behavior observed with the isoprenoid emissions based on in situ PTRMS measurements (inverse Lagrangian transport model). Model emissions of isoprene and total monoterpenes were overestimated, especially during September 2010 (dry season) and December 2010 (wet season), respectively. Total sesquiterpenes were underestimated during November 2010 (dry-to-wet transition season). This difference between MEGAN 2.1 flux estimates and fluxes estimated by the PTRMS vertical mixing ratio profiles could be due to experimental errors or the influence of very local effects on the seasonal emissions measured in this site, because satellite-derived isoprene emissions agree fairly well with MEGAN 2.1 emission estimates and the ground observations do not agree with the satellite data or the model, principally in September. Perhaps the isoprene pattern observed at the site is due to a very local effect of leaf flushing by isoprene emitting species around this tower, but this is not seen on the regional scale where there are different species distributions.

Generally, current models assume that seasonal variation of BVOC emissions in the Amazonian rainforest are primarily based on light and temperature variations. These model simulations capture only a part of the actual variation and have uncertainties associated with the insufficient understanding of mechanistic processes involved in the seasonality of these compounds. Nevertheless, because the number of measurements and sites is limited in Amazonia, there is a scarcity of information, which hinders further model improvements. In summary, our results demonstrate strong seasonality and suggest that important processes are taking place during the transition seasons. Also, results reveal the need for long-term and continuous BVOC observations from leaf level to ecosystem level, and also suggest that standardized measurement procedures are required in order to compare the different Amazonian sub-regions. This may advance understanding of the seasonality of BVOC exchanges between forest and atmosphere, providing the information needed to improve BVOC emission estimates for climate and air quality modeling studies.

Acknowledgements. This work was performed at the National Institute for Amazonian Research and at the State University of Amazonas with funding provided by the $\mathrm{CNPq}$ (fellowship provided to E. Alves by the Brazilian government), and financial support for field work was provided by the Philecology Foundation of Fort Worth, Texas, and the National Science Foundation through the AMAZON-PIRE (Partnerships for International Research 
and Education) award (0730305) and instrumentation support (CHE 0216226). We also thank Scott Saleska for supporting this long field campaign. This research was also supported by the Office of Biological and Environmental Research of the U.S. Department of Energy under Contract No. DE-AC02-05CH11231 as part of their Terrestrial Ecosystem Science Program. The authors would like to acknowledge the advice and support from the Large Biosphere-Atmosphere (LBA) as a part of the Green Ocean Amazon (GoAmazon) 2014/5 project in Manaus, Brazil. T. Stavrakou was supported by the GlobEmission project (No 4000104001/11/I-NB) of the European Space Agency.

Edited by: J. Allan

\section{References}

Ahlm, L., Nilsson, E. D., Krejci, R., Mårtensson, E. M., Vogt, M., and Artaxo, P.: A comparison of dry and wet season aerosol number fluxes over the Amazon rain forest, Atmos. Chem. Phys., 10, 3063-3079, doi:10.5194/acp-10-3063-2010, 2010.

Alves, E. G., Harley, P., Gonçalves, J. F. D. C., Eduardo, C., and Jardine, K.: Effects of light and temperature on isoprene emission at different leaf developmental stages of Eschweilera coriacea in central Amazon, Acta Amazonica, 44, 9-18, doi:10.1590/S0044$59672014000100002,2014$.

Andreae, M. O., Artaxo, P., Brandao, C., Carswell, F. E., Ciccioli, P., da Costa, A. L., Culf, A. D., Esteves, J. L., Gash, J. H. C., Grace, J., Kabat, P., Lelieveld, J., Malhi, Y., Manzi, A. O., Meixner, F. X., Nobre, A. D., Nobre, C., Ruivo, M., Silva-Dias, M. A., Stefani, P., Valentini, R., von Jouanne, J., and Waterloo, M. J.: Biogeochemical cycling of carbon, water, energy, trace gases, and aerosols in Amazonia: The LBA-EUSTACH experiments, J. Geophys. Res., 107, 8066, doi:10.1029/2001jd000524, 2002.

Aquino, C. A. B.: Identificação de Compostos Orgânicos Voláteis (COVs) emitidos por Florestas na região Amazônica, MS thesis. Federal University of Mato Grosso, Cuiabá-MT, Brazil, 106 pp., 2006 (in Portuguese).

Araujo, A. C., Nobre, A. D., Kruijt, B., Elbers, J. A., Dallarosa, R., Stefani, P., von Randow, C., Manzi, A. O., Culf, A. D., Gash, J. H. C., Valentini, R., Kabat, P., and Araújo, A. C.: Comparative measurements of carbon dioxide fluxes from two nearby towers in a central Amazonian rainforest: The Manaus LBA site, J. Geophys. Res., 107, 8090, doi:10.1029/2001jd000676, 2002.

Arneth, A., Niinemets, Ü., Pressley, S., Bäck, J., Hari, P., Karl, T., Noe, S., Prentice, I. C., Serça, D., Hickler, T., Wolf, A., and Smith, B.: Process-based estimates of terrestrial ecosystem isoprene emissions: incorporating the effects of a direct $\mathrm{CO}_{2}$-isoprene interaction, Atmos. Chem. Phys., 7, 31-53, doi:10.5194/acp-7-31-2007, 2007.

Arneth, A., Monson, R. K., Schurgers, G., Niinemets, Ü., and Palmer, P. I.: Why are estimates of global terrestrial isoprene emissions so similar (and why is this not so for monoterpenes)?, Atmos. Chem. Phys., 8, 4605-4620, doi:10.5194/acp-8-46052008, 2008.

Atkinson, R. and Arey, J.: Atmospheric Degradation of Volatile Organic Compounds, Chem. Rev., 103, 4605-4638, doi:10.1021/cr0206420, 2003.
Austin, A. T., Vivanco, L., González-Arzac, A., and Pérez, L. I.: There's no place like home? An exploration of the mechanisms behind plant litter-decomposer affinity in terrestrial ecosystems, New Phytol., 204, 307-314, doi:10.1111/nph.12959, 2014.

Barkley, M. P., Palmer, P. I., Kuhn, U., Kesselmeier, J., Chance, K., Kurosu, T. P., Martin, R. V., Helmig, D., and Guenther, A.: Net ecosystem fluxes of isoprene over tropical South America inferred from Global Ozone Monitoring Experiment (GOME) observations of HCHO columns, J. Geophys. Res., 113, D20304, doi:10.1029/2008JD009863, 2008.

Barkley, M. P., Palmer, P. I., De Smedt, I., Karl, T., Guenther, A., and Van Roozendael, M.: Regulated large-scale annual shutdown of Amazonian isoprene emissions?, Geophys. Res. Lett., 36, L04803, doi:10.1029/2008GL036843, 2009.

Barkley, M. P., De Smedt, I., Van Roozendael, M., Kurosu, T. P., Chance, K., Arneth, A., Hagberg, D., Guenther, A., Paulot, F., Marais, E., and Mao, J.: Top-down isoprene emissions over tropical South America inferred from SCIAMACHY and OMI formaldehyde columns, J. Geophys. Res.-Atmos., 118, 68496868, doi:10.1002/jgrd.50552, 2013.

Bauwens, M., Stavrakou, T., Müller, J. F., De Smedt, I., and Van Roosendael, M.: Satellite-based isoprene emission estimates (2007-2012) from the GlobEmission projet, ACCENTPlus Symposium, Atmospheric Composition Change: the European Network, Urbino, 17-20 September 2013.

Bracho-Nunez, A., Knothe, N. M., Welter, S., Staudt, M., Costa, W. R., Liberato, M. A. R., Piedade, M. T. F., and Kesselmeier, J.: Leaf level emissions of volatile organic compounds (VOC) from some Amazonian and Mediterranean plants, Biogeosciences, 10, 5855-5873, doi:10.5194/bg-10-5855-2013, 2013.

Caldararu, S., Palmer, P. I., and Purves, D. W.: Inferring Amazon leaf demography from satellite observations of leaf area index, Biogeosciences, 9, 1389-1404, doi:10.5194/bg-9-13892012, 2012.

Ciccioli, P., Brancaleoni, E., Frattoni, M., Kuhn, U., Kesselmeir, J., Dindorf, T., De Araujo, A. C., Nobre, A. D., Stefani, P., and Velentini, R.: Fluxes of isoprenoid compounds over the tropical rainforest near Manaus during the dry season and their implications in the ecosystem carbon budget and in the atmospheric chemistry processes, Report Series in Aerosol Science (62A) Proceedings of Integrated Land Ecosystem Atmosphere Processes Study (ILEAPS) International Open Science Conference, Helsinki, Finland, 29 September-3 October, 2003.

Cleveland, C. C. and Yavitt, J. B.: Consumption of atmospheric isoprene in soil, Geophys. Res. Lett., 24, 2379-2382, doi:10.1029/97GL02451, 1997.

Cuartas, L. A., Tomasella, J., Nobre, A. D., Nobre, C. A., Hodnett, M. G., Waterloo, M. J., Oliveira, S. M. De, Randow, R. D. C. Von, Trancoso, R., and Ferreira, M.: Distributed hydrological modeling of a micro-scale rainforest watershed in Amazonia: Model evaluation and advances in calibration using the new HAND terrain model, J. Hydrol., 462-463, 15-27, doi:10.1016/j.jhydrol.2011.12.047, 2012.

da Rocha, H. R., Manzi, A. O., Cabral, O. M., Miller, S. D., Goulden, M. L., Saleska, S. R., R.-Coupe, N., Wofsy, S. C., Borma, L. S., Artaxo, P., Vourlitis, G., Nogueira, J. S., Cardoso, F. L., Nobre, A. D., Kruijt, B., Freitas, H. C., von Randow, C., Aguiar, R. G., and Maia, J. F.: Patterns of water and heat flux across a biome gradient from tropical forest to savanna in Brazil, 
J. Geophys. Res., 114, G00B12, doi:10.1029/2007JG000640, 2009.

Davis, K. J., Lenschow, D. H., and Zimmerman, P. R.: Biogenic nonmethane hydrocarbon emissions estimated from tethered balloon observations, J. Geophys. Res., 99, 25587, doi:10.1029/94JD02009, 1994.

Duhl, T. R., Helmig, D., and Guenther, A.: Sesquiterpene emissions from vegetation: a review, Biogeosciences, 5, 761-777, doi:10.5194/bg-5-761-2008, 2008.

Fidelis, C. H. V., Augusto, F., Sampaio, P. T. B., Krainovic, P. M., and Barata, L. E. S.: Chemical characterization of rosewood (Aniba rosaeodora Ducke) leaf essential oil by comprehensive two-dimensional gas chromatography coupled with quadrupole mass spectrometry, J. Essent. Oil Res., 24, 245-251, doi:10.1080/10412905.2012.676770, 2012.

Geron, C., Rasmussen, R., Arnts, R. R., and Guenther, A.: A review and synthesis of monoterpene speciation from forests in the United States, Atmos. Environ., 34, 1761-1781, doi:10.1016/S1352-2310(99)00364-7, 2000.

Goldan, P. D., Kuster, W. C., Fehseneld, F. C., and Montzka, S. A.: Hydrocarbon measurements in the southeastern United States: The Rural Oxidants in the Southern Environment (ROSE) Program 1990, J. Geophys. Res., 100, 25945, doi:10.1029/95JD02607, 1995.

Goldstein, A. H. and Galbally, I. E.: Known and Unexplored Organic Constituents in the Earth's Atmosphere, Environ. Sci. Technol., 41, 1514-1521, doi:10.1021/es072476p, 2007.

Gray, C. M., Monson, R. K., and Fierer, N.: Biotic and abiotic controls on biogenic volatile organic compound fluxes from a subalpine forest floor, J. Geophys. Res. Biogeo., 119, 547-556, doi:10.1002/2013JG002575, 2014.

Greenberg, J. P. and Zimmerman, P. R.: Nonmethane hydrocarbons in remote tropical, continental, and marine atmospheres, J. Geophys. Res., 89, 4767, doi:10.1029/JD089iD03p04767, 1984.

Greenberg, J. P., Guenther, A. B., Petron, G., Wiedinmyer, C., Vega, O., Gatti, L. V, Tota, J., and Fisch, G.: Biogenic VOC emissions from forested Amazonian landscapes, Glob. Change Biol., 10, 651-662, doi:10.1111/j.1365-2486.2004.00758.x, 2004.

Grote, R., Morfopoulos, C., Niinemets, Ü., Sun, Z., Keenan, T. F., Pacifico, F., and Butler, T.: A fully integrated isoprenoid emissions model coupling emissions to photosynthetic characteristics, Plant Cell Environ., 37, 1965-80, doi:10.1111/pce.12326, 2014.

Guenther, A.: The contribution of reactive carbon emissions from vegetation to the carbon balance of terrestrial ecosystems, Chemosphere, 49, 837-44, doi:10.1016/S0045-6535(02)003843, 2002.

Guenther, A., Karl, T., Harley, P., Wiedinmyer, C., Palmer, P. I., and Geron, C.: Estimates of global terrestrial isoprene emissions using MEGAN (Model of Emissions of Gases and Aerosols from Nature), Atmos. Chem. Phys., 6, 3181-3210, doi:10.5194/acp-63181-2006, 2006.

Guenther, A. B.: Upscaling biogenic volatile compound emissions from leaves to landscapes, in Biology, controls and models of tree volatile organic compound emissions, edited by: Niinemets, Ü. and Monson, R. K., Springer, Berlin, 391-414, 2013.

Guenther, A. B., Jiang, X., Heald, C. L., Sakulyanontvittaya, T., Duhl, T., Emmons, L. K., and Wang, X.: The Model of Emissions of Gases and Aerosols from Nature version 2.1 (MEGAN2.1): an extended and updated framework for modeling biogenic emissions, Geosci. Model Dev., 5, 1471-1492, doi:10.5194/gmd-51471-2012, 2012.

Hamba, A.: Modified K model for chemically reactive species in the planetary boundary layer, J. Geophys. Res., 98, 5173-5182, doi:10.1029/92JD02511, 1993.

Hanna, S. R., Russel, A. G., Wilkinson, J. G., Vukovich, J., and Hansen, D. A.: Monte Carlo estimation of uncertainties in BEIS3 emission outputs and their effects on uncertainties in chemical transport model predictions. J. Geophys. Res., 110, D01302, doi:10.1029/2004JD004986, 2005.

Harley, P., Vasconcellos, P., Vierling, L., Pinheiro, C. C. d. S., Greenberg, J., Guenther, A., Klinger, L., Almeida, S. S. d., Neill, D., Baker, T., Phillips, O., and Malhi, Y.: Variation in potential for isoprene emissions among Neotropical forest sites, Glob. Change Biol., 10, 630-650, doi:10.1111/j.15298817.2003.00760.x, 2004.

Helmig, D., Balsley, B., Kuck, R., Jensen, M., Smith, T., and Birks, J. W.: Vertical profiling and determination of landscape fluxes of biogenic nonmethane hydrocarbons within the planetary boundary layer in the Peruvian Amazon, J. Geophys. Res., 103, 519532, doi:10.1029/98JD01023, 1998.

Jacob, D. J. and Wofsy, S. C.: Photochemistry of biogenic emissions over the Amazon forest, J. Geophys. Res., 93, 1477-1486, doi:10.1029/JD093iD02p01477, 1988.

Jardine, A. B., Jardine, K. J., Fuentes, J. D., Martin, S. T., Martins, G., Durgante, F., Carneiro, V., Higuchi, N., Manzi, A. O., and Chambers, J. Q.: Highly reactive light-dependent monoterpenes in the Amazon, Geophys. Res. Lett., 42, 1-8, doi:10.1002/2014GL062573, 2015.

Jardine, K., Yañez Serrano, A., Arneth, A., Abrell, L., Jardine, A., van Haren, J., Artaxo, P., Rizzo, L. V., Ishida, F. Y., Karl, T., Kesselmeier, J., Saleska, S., and Huxman, T.: Within-canopy sesquiterpene ozonolysis in Amazonia, J. Geophys. Res., 116, D19301, doi:10.1029/2011jd016243, 2011.

Jardine, K. J., Henderson, W. M., Huxman, T. E., and Abrell, L.: Dynamic Solution Injection: a new method for preparing pptvppbv standard atmospheres of volatile organic compounds, Atmos. Meas. Tech., 3, 1569-1576, doi:10.5194/amt-3-1569-2010, 2010.

Jardine, K. J., Monson, R. K., Abrell, L., Saleska, S. R., Arneth, A., Jardine, A., Ishida, F. Y., Serrano, A. M. Y., Artaxo, P., Karl, T., Fares, S., Goldstein, A., Loreto, F., and Huxman, T.: Within-plant isoprene oxidation confirmed by direct emissions of oxidation products methyl vinyl ketone and methacrolein, Glob. Change Biol., 18, 973-984, doi:10.1111/j.1365-2486.2011.02610.x, 2012.

Jones, M. O., Kimball, J. S., and Nemani, R. R.: Asynchronous Amazon forest canopy phenology indicates adaptation to both water and light availability, Environ. Res. Lett., 9, 124021, doi:10.1088/1748-9326/9/12/124021, 2014.

Karl, T., Potosnak, M., Guenther, A. B., Clark, D., Walker, J., Herrick, J. D., and Geron, C.: Exchange processes of volatile organic compounds above a tropical rain forest: Implications for modeling tropospheric chemistry above dense vegetation, J. Geophys. Res., 109, D18306, doi:10.1029/2004JD004738, 2004.

Karl, T., Guenther, A., Yokelson, R. J., Greenberg, J., Potosnak, M., Blake, D. R., and Artaxo, P.: The tropical forest and fire emissions experiment: Emission, chemistry, and trans- 
port of biogenic volatile organic compounds in the lower atmosphere over Amazonia, J. Geophys. Res., 112, D18302, doi:10.1029/2007JD008539, 2007.

Karl, T., Guenther, A., Turnipseed, A., Tyndall, G., Artaxo, P., and Martin, S.: Rapid formation of isoprene photo-oxidation products observed in Amazonia, Atmos. Chem. Phys., 9, 7753-7767, doi:10.5194/acp-9-7753-2009, 2009.

Karl, T., Harley, P., Emmons, L., Thornton, B., Guenther, A., Basu, C., Turnipseed, A., and Jardine, K.: Efficient Atmospheric Cleansing of Oxidized Organic Trace Gases by Vegetation, Science, 330, 816-819, doi:10.1126/science.1192534, 2010.

Kesselmeier, J., Kuhn, U., Wolf, A., Andreae, M., Ciccioli, P., Brancaleoni, E., Frattoni, M., Guenther, A., Greenberg, J., De Castro Vasconcellos, P., de Oliva, T., Tavares, T., and Artaxo, P.: Atmospheric volatile organic compounds (VOC) at a remote tropical forest site in central Amazonia, Atmos. Environ., 34, 4063-4072, doi:10.1016/S1352-2310(00)00186-2, 2000.

Kesselmeier, J., Kuhn, U., Rottenberger, S., Biesenthal, T., Wolf, A., Schebeske, G., Andreae, M. O., Ciccioli, P., Brancaleoni, E., Frattoni, M., Oliva, S. T., Botelho, M. L., Silva, C. M. A., and Tavares, T. M.: Concentrations and species composition of atmospheric volatile organic compounds (VOCs) as observed during the wet and dry season in Rondônia (Amazonia), J. Geophys. Res., 107, 8053, doi:10.1029/2000JD000267, 2002.

Kuhn, U., Rottenberger, S., Biesenthal, T., Wolf, A., Schebeske, G., Ciccioli, P., Brancaleoni, E., Frattoni, M., Tavares, T. M., and Kesselmeier, J.: Isoprene and monoterpene emissions of Amazonian tree species during the wet season: Direct and indirect investigations on controlling environmental functions, J. Geophys. Res., 107, 8071, doi:10.1029/2001jd000978, 2002.

Kuhn, U., Rottenberger, S., Biesenthal, T., Wolf, A., Schebeske, G., Ciccioli, P., Brancaleoni, E., Frattoni, M., Tavares, T. M., and Kesselmeier, J.: Seasonal differences in isoprene and light-dependent monoterpene emission by Amazonian tree species, Glob. Change Biol., 10, 663-682, doi:10.1111/j.15298817.2003.00771.x, 2004a.

Kuhn, U., Rottenberger, S., Biesenthal, T., Wolf, A., Schebeske, G., Ciccioli, P., and Kesselmeier, J.: Strong correlation between isoprene emission and gross photosynthetic capacity during leaf phenology of the tropical tree species Hymenaea courbaril with fundamental changes in volatile organic compounds emission composition during early leaf development, Plant Cell Environ., 27, 1469-1485, doi:10.1111/j.1365-3040.2004.01252.x, 2004b.

Kuhn, U., Andreae, M. O., Ammann, C., Araújo, A. C., Brancaleoni, E., Ciccioli, P., Dindorf, T., Frattoni, M., Gatti, L. V., Ganzeveld, L., Kruijt, B., Lelieveld, J., Lloyd, J., Meixner, F. X., Nobre, A. D., Pöschl, U., Spirig, C., Stefani, P., Thielmann, A., Valentini, R., and Kesselmeier, J.: Isoprene and monoterpene fluxes from Central Amazonian rainforest inferred from towerbased and airborne measurements, and implications on the atmospheric chemistry and the local carbon budget, Atmos. Chem. Phys., 7, 2855-2879, doi:10.5194/acp-7-2855-2007, 2007.

Lamb, B., Guenther, A., Gay, D., and Westberg, H.: A National Inventory of Biogenic Hydrocarbon Emissions, Atmos. Environ., 21, 1695-1705, doi:10.1016/0004-6981(87)90108-9, 1987.

Lamb, B., Pierce, T., Baldocchi, D., Allwine, E., Dilts, S., Westberg, H., Geron, C., Guenther, A., Klinger, L., Harley, P., and Zimmerman, P.: Evaluation of forest canopy models for estimat- ing isoprene emissions, J. Geophys. Res., 101, 22787-22797, doi:10.1029/96JD00056, 1996.

Laothawornkitkul, J., Taylor, J. E., Paul, N. D., and Hewitt, C. N.: Biogenic volatile organic compounds in the Earth system, New Phytol., 183, 27-51, doi:10.1111/j.1469-8137.2009.02859.x, 2009.

Lelieveld, J., Butler, T. M., Crowley, J. N., Dillon, T. J., Fischer, H., Ganzeveld, L., Harder, H., Lawrence, M. G., Martinez, M., Taraborrelli, D., and Williams, J.: Atmospheric oxidation capacity sustained by a tropical forest, Nature, 452, 737-40, doi:10.1038/nature06870, 2008.

Lima, P. M., Zoghbi, G. B., Andrade, E. H. A., Silva, T. M., and Fernandes, C. S.: Constituintes voláteis das folhas e dos galhos de Cinnamomum zeylanicum Blume (Lauraceae), Volatile constituents from leaves and branches of Cinnamomum zeylanicum Blume (Lauraceae), Acta Amazonica, 35, 363-366, 2005.

Lindinger, W., Hansel, A., and Jordan, A.: On-line monitoring of volatile organic compounds at pptv levels by means of protontransfer-reaction mass spectrometry (PTR-MS) medical applications, food control and environmental research, Int. J. Mass Spectrom., 173, 191-241, doi:10.1016/S0168-1176(97)00281-4, 1998.

Liu, Y. J., Herdlinger-Blatt, I., McKinney, K. A., and Martin, S. T.: Production of methyl vinyl ketone and methacrolein via the hydroperoxyl pathway of isoprene oxidation, Atmos. Chem. Phys., 13, 5715-5730, doi:10.5194/acp-13-5715-2013, 2013.

Loreto, F., Ciccioli, P., Cecinato, A., Brancaleoni, E., Frattoni, M., Fabozzi, C., and Tricoli, D.: Evidence of the Photosynthetic Origin of Monoterpenes Emitted by Quercus ilex L. Leaves by ${ }^{13} \mathrm{C}$ Labeling, Plant Physiol., 110, 1317-1322, 1996.

Luizão, F. J.: Litter production and mineral element input to the forest floor in a central Amazonian forest, GeoJournal, 19, 407417, 1989.

Malhi, Y., Aragão, L. E. O. C., Metcalfe, D. B., Paiva, R., Quesada, C. A., Almeida, S., Anderson, L., Brando, P., Chambers, J. Q., da Costa, A. C. L., Hutyra, L. R., Oliveira, P., Patiño, S., Pyle, E. H., Robertson, A. L., and Teixeira, L. M.: Comprehensive assessment of carbon productivity, allocation and storage in three Amazonian forests, Glob. Change Biol., 15, 1255-1274, doi:10.1111/j.1365-2486.2008.01780.x, 2009.

Marengo, J. A., Nobre, C. A., Tomasella, J., Oyama, M. D., Sampaio de Oliveira, G., de Oliveira, R., Camargo, H., Alves, L. M., and Brown, I. F.: The Drought of Amazonia in 2005, J. Climate, 21, 495-516, doi:10.1175/2007JCLI1600.1, 2008.

Marengo, J. A., Tomasella, J., Alves, L. M., Soares, W. R., and Rodriguez, D. A.: The drought of 2010 in the context of historical droughts in the Amazon region, Geophys. Res. Lett., 38, 1-5, doi:10.1029/2011GL047436, 2011.

Martin, S. T., Andreae, M. O., Althausen, D., Artaxo, P., Baars, H., Borrmann, S., Chen, Q., Farmer, D. K., Guenther, A., Gunthe, S. S., Jimenez, J. L., Karl, T., Longo, K., Manzi, A., Müller, T., Pauliquevis, T., Petters, M. D., Prenni, A. J., Pöschl, U., Rizzo, L. V., Schneider, J., Smith, J. N., Swietlicki, E., Tota, J., Wang, J., Wiedensohler, A., and Zorn, S. R.: An overview of the Amazonian Aerosol Characterization Experiment 2008 (AMAZE08), Atmos. Chem. Phys., 10, 11415-11438, doi:10.5194/acp10-11415-2010, 2010.

Misztal, P. K., Karl, T., Weber, R., Jonsson, H. H., Guenther, A. B., and Goldstein, A. H.: Airborne flux measurements of bio- 
genic isoprene over California, Atmos. Chem. Phys., 14, 1063110647, doi:10.5194/acp-14-10631-2014, 2014.

MODIS-NASA: Leaf Area Index - Fraction of Photosynthetically Active Radiation 8-Day L4 Global $1 \mathrm{~km}$, available at: https://lpdaac.usgs.gov/dataset_discovery/modis/modis, (last access: 25 July 2015), 2015.

Monson, R. K., Grote, R., Niinemets, Ü., and Schnitzler, J.-P.: Modeling the isoprene emission rate from leaves, 195, 541-559, doi:10.1111/j.1469-8137.2012.04204.x, 2012.

Morfopoulos, C., Prentice, I. C., Keenan, T. F., Friedlingstein, P., Medlyn, B. E., Peñuelas, J., and Possell, M.: A unifying conceptual model for the environmental responses of isoprene emissions from plants, Ann. Bot., 112, 1223-1238, doi:10.1093/aob/mct206, 2013.

Morfopoulos, C., Sperlich, D., Pe, J., Filella, I., Llusi, J., Possell, M., Sun, Z., Prentice, I. C., and Medlyn, B. E.: A model of plant isoprene emission based on available reducing power captures responses to atmospheric $\mathrm{CO}_{2}$, New Phytol., 203 , 125139, doi:10.1111/nph.12770, 2014.

Morton, D. C., Nagol, J., Carabajal, C. C., Rosette, J., Palace, M., Cook, B. D., Vermote, E. F., Harding, D. J., and North, P. R. J.: Amazon forests maintain consistent canopy structure and greenness during the dry season, Nature, 506, 221-224, doi:10.1038/nature13006, 2014.

Müller, J.-F., Stavrakou, T., Wallens, S., De Smedt, I., Van Roozendael, M., Potosnak, M. J., Rinne, J., Munger, B., Goldstein, A., and Guenther, A. B.: Global isoprene emissions estimated using MEGAN, ECMWF analyses and a detailed canopy environment model, Atmos. Chem. Phys., 8, 1329-1341, doi:10.5194/acp-81329-2008, 2008.

Myneni, R. B., Yang, W., Nemani, R. R., Huete, A. R., Dickinson, R. E., Knyazikhin, Y., Didan, K., Fu, R., Negrón Juárez, R. I., Saatchi, S. S., Hashimoto, H., Ichii, K., Shabanov, N. V, Tan, B., Ratana, P., Privette, J. L., Morisette, J. T., Vermote, E. F., Roy, D. P., Wolfe, R. E., Friedl, M. A., Running, S. W., Votava, P., El-Saleous, N., Devadiga, S., Su, Y., and Salomonson, V. V: Large seasonal swings in leaf area of Amazon rainforests, P. Natl. Acad. Sci. USA, 104, 4820-4823, doi:10.1073/pnas.0611338104, 2007.

Nelson, B., Tavares, J., Wu, J., Valeriano, D., Lopes, A., Marostica, S., Martins, G., Prohaska, N., Albert, L., De Araújo, A., Manzi, A., Saleska, S., and Huete, A.: Seasonality of central Amazon Forest Leaf Flush using tower mounted RGB Camera, AGU Fall Meeting, San Francisco, California, 15-19 December 2014, B11G-0107, 2014.

Nemitz, E., Sutton, M. A., Gut, A., San José, R., Husted, S., and Schjoerring, J. K.: Sources and sinks of ammonia within an oilseed rape canopy, Agr. Forest Meteorol., 105, 385-404, doi:10.1016/S0168-1923(00)00205-7, 2000.

Oliveira, A. N., Braule, M., Ramos, P., Couto, L. B., and Sahdo, R. M.: Composição e diversidade florístico-estrutural de um hectare de floresta densa de terra firme na Amazônia, Acta Amazonica, 38, 627-642, doi:10.1590/S0044-59672008000400005, 2008.

Park, J.-H., Goldstein, A. H., Timkovsky, J., Fares, S., Weber, R., Karlik, J., and Holzinger, R.: Active atmosphere-ecosystem exchange of the vast majority of detected volatile organic compounds, Science, 341, 643-647, doi:10.1126/science.1235053, 2013.
Parker, G. and Fitzjarrald, D. R.: Canopy structure and radiation environment metrics indicate forest developmental stage, disturbance, and certain ecosystem functions, III LBA Scientific Conference, 27-29 July 2004, Braz. Minist. of Sci. and Technol., Brasilia, Brazil, 2004.

Pires, J. M. and Prance, G. T.: Key environments: Amazonia, in: Vegetation types of the Brazilian Amazonia, edited by: Prance, G. T. and Lovejoy, T. E., Pergamon, New York, 1985.

Rasmussen, R. A. and Khalil, M. A. K.: Isoprene over the Amazon Basin, J. Geophys. Res., 93, 1417, doi:10.1029/JD093iD02p01417, 1988.

Raupach, M.: Applying Lagrangian Fluid Mechanics to infer scalar source distributions from concentration profiles in plant canopies, Agr. Forest Meteorol., 47, 85-108, doi:10.1016/01681923(89)90089-0, 1989.

Restrepo-Coupe, N., da Rocha, H. R., Hutyra, L. R., da Araujo, A. C., Borma, L. S., Christoffersen, B., Cabral, O. M. R. R., de Camargo, P. B., Cardoso, F. L., da Costa, A. C. L., Fitzjarrald, D. R., Goulden, M. L., Kruijt, B., Maia, J. M. F. F., Malhi, Y. S., Manzi, A. O., Miller, S. D., Nobre, A. D., von Randow, C., Sá, L. D. A., Sakai, R. K., Tota, J., Wofsy, S. C., Zanchi, F. B., and Saleska, S. R.: What drives the seasonality of photosynthesis across the Amazon basin? A cross-site analysis of eddy flux tower measurements from the Brasil flux network, Agr. Forest Meteorol., 182-183, 128-144, doi:10.1016/j.agrformet.2013.04.031, 2013.

Rinne, H. J. I., Guenther, A. B., Greenberg, J. P., and Harley, P. C.: Isoprene and monoterpene fluxes measured above Amazonian rainforest and their dependence on light and temperature, Atmos. Environ., 36, 2421-2426, doi:10.1016/S1352-2310(01)00523-4, 2002.

Rizzo, L. V. V., Artaxo, P., Karl, T., Guenther, A. B. B., and Greenberg, J.: Aerosol properties, in-canopy gradients, turbulent fluxes and VOC concentrations at a pristine forest site in Amazonia, Atmos. Environ., 44, 503-511, doi:10.1016/j.atmosenv.2009.11.002, 2010.

Samanta, A., Knyazikhin, Y., Xu, L., Dickinson, R. E., Fu, R., Costa, M. H., Saatchi, S. S., Nemani, R. R. and Myneni, R. B.: Seasonal changes in leaf area of Amazon forests from leaf flushing and abscission, J. Geophys. Res., 117, G01015, doi:10.1029/2011JG001818, 2012.

Silva, C. P.: Estudos observacionais das principais fontes de emissão de compostos orgânicos voláteis (VOC) em floresta intacta de terra firme na Amazônia Central, MS thesis, National Institute for Amazon Research, Manaus-AM, Brazil, 91 pp., 2010 (in Portuguese).

Silva, F. B., Shimabukuro, Y. E., Aragão, L. E. O. C., Anderson, L. O., Pereira, G., Cardozo, F., and Arai, E.: Corrigendum: Large-scale heterogeneity of Amazonian phenology revealed from 26-year long AVHRR/NDVI time-series, Environ. Res. Lett., 8, 029502, doi:10.1088/1748-9326/8/2/029502, 2013.

Simon, E., Meixner, F. X., Rummel, U., Ganzeveld, L., Ammann, C., and Kesselmeier, J.: Coupled carbon-water exchange of the Amazon rain forest, II. Comparison of predicted and observed seasonal exchange of energy, $\mathrm{CO}_{2}$, isoprene and ozone at a remote site in Rondônia, Biogeosciences, 2, 255-275, doi:10.5194/bg-2-255-2005, 2005.

Stark, S. C., Leitold, V., Wu, J. L., Hunter, M. O., de Castilho, C. V, Costa, F. R. C., McMahon, S. M., Parker, G. G., Shimabukuro, 
M. T., Lefsky, M. A., Keller, M., Alves, L. F., Schietti, J., Shimabukuro, Y. E., Brandão, D. O., Woodcock, T. K., Higuchi, N., de Camargo, P. B., de Oliveira, R. C., Saleska, S. R., and Chave, J.: Amazon forest carbon dynamics predicted by profiles of canopy leaf area and light environment, Ecol. Lett., 15, 140614, doi:10.1111/j.1461-0248.2012.01864.x, 2012.

Stavrakou, T., Müller, J.-F., De Smedt, I., Van Roozendael, M., van der Werf, G. R., Giglio, L., and Guenther, A.: Global emissions of non-methane hydrocarbons deduced from SCIAMACHY formaldehyde columns through 2003-2006, Atmos. Chem. Phys., 9, 3663-3679, doi:10.5194/acp-9-3663-2009, 2009.

Stavrakou, T., Müller, J.-F., Bauwens, M., De Smedt, I., Van Roozendael, M., Guenther, A., Wild, M., and Xia, X.: Isoprene emissions over Asia 1979-2012: impact of climate and land-use changes, Atmos. Chem. Phys., 14, 4587-4605, doi:10.5194/acp-14-4587-2014, 2014.

Stavrakou, T., Müller, J.-F., Bauwens, M., De Smedt, I., Van Roozendael, M., De Mazière, M., Vigouroux, C., Hendrick, F., George, M., Clerbaux, C., Coheur, P.-F., and Guenther, A.: How consistent are top-down hydrocarbon emissions based on formaldehyde observations from GOME-2 and OMI?, Atmos. Chem. Phys., 15, 11861-11884, doi:10.5194/acp-1511861-2015, 2015

Stefani, P.: Preliminary assessment of VOC fluxes from a primary rain forest performed in the LBA site at Manaus, LBA First Scientific Conference, 2-4 June 2000, Braz. Minist. of Sci. and Technol., Belém, Brazil, 2000.

Tavares, J. V.: Green-up na Estação Seca da Amazônia Central: Padrões sazonais da fenologia foliar de uma floresta de terra firme, MS thesis, National Institute for Amazon Research, Manaus-AM, Brazil, 40 pp., 2013 (in Portuguese).
Trostdorf, C. R., Gatti, L. V., Yamazaki, A., Potosnak, M. J., Guenther, A., Martins, W. C., and Munger, J. W.: Seasonal cycles of isoprene concentrations in the Amazonian rainforest, Atmos. Chem. Phys. Discuss., 4, 1291-1310, doi:10.5194/acpd-4-12912004, 2004.

Unger, N., Harper, K., Zheng, Y., Kiang, N. Y., Aleinov, I., Arneth, A., Schurgers, G., Amelynck, C., Goldstein, A., Guenther, A., Heinesch, B., Hewitt, C. N., Karl, T., Laffineur, Q., Langford, B., A. McKinney, K., Misztal, P., Potosnak, M., Rinne, J., Pressley, S., Schoon, N., and Serça, D.: Photosynthesis-dependent isoprene emission from leaf to planet in a global carbonchemistry-climate model, Atmos. Chem. Phys., 13, 1024310269, doi:10.5194/acp-13-10243-2013, 2013.

Warneke, C., Gouw, J. A., Del Negro, L., Brioude, J., Mckeen, S., Stark, H., Kuster, W. C., Goldan, P. D., Trainer, M., Fehsenfeld, F. C., Wiedinmyer, C., Guenther, A. B., Hansel, A., Wisthaler, A., Atlas, E., Holloway, J. S., Ryerson, T. B., Peischl, J., Huey, L. G., and Hanks, A. T. Case: Biogenic emission measurement and inventories determination of biogenic emissions in the eastern United States and Texas and comparison with biogenic emission inventories, J. Geophys. Res., 115, D00F18, doi:10.1029/2009JD012445, 2010.

Yáñez-Serrano, A. M., Nölscher, A. C., Williams, J., Wolff, S., Alves, E., Martins, G. A., Bourtsoukidis, E., Brito, J., Jardine, K., Artaxo, P., and Kesselmeier, J.: Diel and seasonal changes of biogenic volatile organic compounds within and above an Amazonian rainforest, Atmos. Chem. Phys., 15, 3359-3378, doi:10.5194/acp-15-3359-2015, 2015.

Zimmerman, P. R., Greenberg, J. P., and Westberg, C. E.: Measurements of atmospheric hydrocarbons and biogenic emission fluxes in the Amazon Boundary layer, J. Geophys. Res., 93, 1407, doi:10.1029/JD093iD02p01407, 1988. 